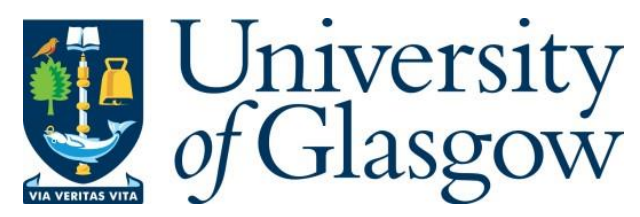

Pret, T. and Carter, S. (2017) The importance of 'fitting in': collaboration and social value creation in response to community norms and expectations. Entrepreneurship and Regional Development, 29(7-8), pp. 639-667.

There may be differences between this version and the published version. You are advised to consult the publisher's version if you wish to cite from it.

http://eprints.gla.ac.uk/215413/

Deposited on: 4 May 2020

Enlighten - Research publications by members of the University of Glasgow http://eprints.gla.ac.uk 


\section{THE IMPORTANCE OF 'FITTING IN': COLLABORATION AND SOCIAL VALUE CREATION IN RESPONSE TO COMMUNITY NORMS AND EXPECTATIONS}

Tobias Pret, Lubin School of Business, Pace University, 1 Pace Plaza, New York, NY 10038, USA. Email: tpret@pace.edu (Corresponding Author)

Sara Carter, Hunter Centre for Entrepreneurship, University of Strathclyde, 130 Rottenrow, Glasgow, G4 0GE, UK. Email: sara.carter@strath.ac.uk; Telephone: 01415483276

\section{Acknowledgements}

The authors would like to thank the editors and the anonymous reviewers for their excellent suggestions and guidance. They would also like to express their gratitude for the constructive and insightful comments provided by Sarah Drakopoulou Dodd and Aviel Dodge-Cogan. 


\title{
THE IMPORTANCE OF 'FITTING IN': COLLABORATION AND SOCIAL VALUE CREATION IN RESPONSE TO COMMUNITY NORMS AND EXPECTATIONS
}

\begin{abstract}
This article explores the effects of embeddedness in communities upon entrepreneurial practices. Based on the lived experiences of 10 craft entrepreneurs, this article reveals that within certain contexts, such as craft communities, entrepreneurs are expected to exhibit high levels of camaraderie and generosity, which leads them to create social value by supporting their peers and freely sharing their resources. Craft entrepreneurs achieve 'fitting in' not only by learning accepted norms, but also by performing strategic actions which allow them to temporarily adapt their conduct to meet the expectations of community members. Thus, this paper exposes a largely concealed element of social entrepreneurial practice. This article also reveals that embeddedness in communities can lead entrepreneurs to collaborate with potential competitors. Craft entrepreneurs share their economic, cultural, social and symbolic capital in order to support and help revitalise their communities, to perpetuate their respective industries, and to sustain a genuine interest in hand-crafted products. Craft entrepreneurs consider such supportive behaviour a social responsibility that is shared among community members and a task that is passed from one generation to the next. Thus, this article reveals that collaboration and social value creation can be embraced in response to community norms and expectations.
\end{abstract}

\section{Keywords}

Community, Collaboration, Embeddedness, Social Entrepreneurship, Practice Theory, Craft Entrepreneurs, Cultural Industries, Bourdieu

\section{Introduction}

Context matters - it can both facilitate and restrict entrepreneurial actions (Aldrich and Fiol 1994; Mair, Martí, and Ventresca 2012; Welter 2011). Prior studies reveal that embeddedness in social and spatial contexts can provide entrepreneurs with opportunities for collaboration (Coulson 2012; Di Domenico, Tracey, and Haugh 2009), access to resources (Batjargal 2003; Hite 2005) and valuable advice and information (Chalmers and Balan-Vnuk 2013; Johannisson, Ramírez-Pasillas, and Karlsson 2002). As such, it can contribute to the creation of value (Mair and Marti 2006; Smith and Stevens 2010) and the discovery and exploitation of opportunities (Korsgaard, Ferguson, and Gaddefors 2015; Vershinina, Barrett, and Meyer 2011). However, embeddedness usually comes at a price: to gain acceptance and to receive the support of other embedded agents, entrepreneurs must comply with certain context-specific norms and conventions (Fisher, Kotha, and Lahiri 2016; Lounsbury and Glynn 2001). As Jack and Anderson $(2002,483)$ note, 'failing to conform to expectations or implicit rules may sour relationships and become hindrances to business operations'. While several theories have been 
proposed to explain how and why entrepreneurs may adapt their behaviours to fit in with prevailing conventions (De Clercq and Honig 2011; De Clercq and Voronov 2009), empirical studies of these entrepreneurial practices are rare (Stringfellow, Shaw, and Maclean 2014).

As accepted norms and rules vary significantly between individual contexts (Lang, Fink, and Kibler 2014; Parkinson, Howorth, and Southern, Forthcoming), it has been suggested that entrepreneurs be studied 'within their natural settings' (Zahra, Wright, and Abdelgawad 2014, 481) to gain deeper knowledge of their behaviours. Despite the increasing number of context-focussed entrepreneurship studies, there remain enduring gaps in understanding concerning the effects of contextual embeddedness on different entrepreneurial practices (Welter 2011). Accordingly, due to 'the heterogeneous contexts in which social enterprise and social innovation can occur' (Shaw and de Bruin 2013, 742), there have been repeated call for research to investigate the significance of context in social entrepreneurship (de Bruin and Lewis 2015; Short, Moss, and Lumpkin 2009). While embeddedness in institutional contexts (Battilana and Lee 2014; Pache and Santos 2013; Wry and York, Forthcoming) and social networks (Haugh 2007; Kistruck and Beamish 2010; Shaw and Carter 2007) have received considerable scholarly attention, community embeddedness and its influences on social entrepreneurs are acknowledged as under-explored (Barth et al. 2015; Hindle 2010). Cultural, virtual and transnational communities in particular have not received adequate consideration (Dana and Light 2011; O'Mahony and Ferraro 2007), despite their increasing importance in the modern age. This lack of attention is due to the prevailing understanding of communities as geographically bound groups of actors (Jennings et al. 2013). This article therefore employs a more inclusive definition of communities, developed by Marquis, Lounsbury and Greenwood (2011, xvi):

Communities are collections of actors whose membership in the collective provides social and cultural resources that shape their action. Membership can result from a number of factors including propinquity, interest in a common goal, or common identity.

This conceptualisation acknowledges that 'social bonds and an affinity to community' (McKeever, Jack, and Anderson 2015, 62) can shape the behaviours of entrepreneurs regardless of their geographic location (Maurer and Ebers 2006).

Within the emerging body of community-focussed entrepreneurship research, there is a growing recognition that 'enterprising people [devise] small-scale and simple collaborative solutions to address the social 
needs that exist in their local communities' (Zahra et al. 2009, 525). Indeed, it has been suggested that interorganisational collaboration can generate greater social impact (Austin, Stevenson, and Wei-Skillern 2006). As Pearce and Doh $(2006,32)$ argue, within collaborative social initiatives, 'each partner [venture] benefits when the other brings resources, capabilities or other assets that it cannot easily attain on its own.' Accordingly, there has been growing interest in exploring the ways in which collaboration among entrepreneurs facilitates social value creation (Akemu, Whiteman, and Kennedy 2016; Barth et al. 2015). However, little is known about how and why social and moral obligations within community contexts may compel entrepreneurs to support collective social endeavours (de Bruin and Lewis 2015; Di Domenico, Tracey, and Haugh 2009). This article seeks to address this gap and advance knowledge by exploring the perspectives of entrepreneurs who have become embedded in communities that encourage collaboration and social value creation. Specifically, this paper investigates (1) how and why entrepreneurs adapt their behaviours to fit in with community norms and expectations and (2) how and why embeddedness in community contexts might promote socially oriented business practices.

This article adopts an interpretative phenomenological approach (Cope 2011; Lewis 2015; Pret, Shaw, and Drakopoulou Dodd 2016) and investigates the lived experiences of 10 craft entrepreneurs, who promote community and social growth. Prior research reveals that craft entrepreneurs are driven by a number of divergent motivations, requiring them 'to constantly strike balances between goals of lifestyle, community involvement and commercial success' (Tregear 2005, 1). In addition to crafting products that are both commercially valuable and true to their artistic self-expression (Eikhof and Haunschild 2007), craft entrepreneurs create social value through work in the community, such as by offering classes to help students develop their confidence and by fostering inclusion and social interaction through shared activities (Schwarz and Yair 2010). This article shows how craft entrepreneurs manage to reconcile social value creation with the need for commercial sustainability and success. Our participants survive in areas with limited employment prospects and contribute to reviving these rural regions. By opening and operating shops in deprived areas, craft entrepreneurs support local regeneration efforts (Bertacchini and Borrione 2011) and, as their businesses grow, they create new employment opportunities (Bhagavatula et al. 2010). Furthermore, craft entrepreneurs encourage tourism to their local areas through their engagement in virtual craft communities, which consist of highly committed collectors who often 
seek to visit makers in person. As shown in this article, through collaboration and sharing of resources, craft entrepreneurs also ensure the long-term survival of their respective industries. Sustaining diverse forms of artistic expression for generations to come is arguably not only a social good in itself, but also generates additional social value by preserving the opportunities and employment created by those industries. Thus, while we label participants as craft entrepreneurs, we consider them to be social entrepreneurs, as well.

This article makes several theoretical and empirical contributions. It reveals that within certain contexts, such as craft communities, entrepreneurs are expected to exhibit high levels of positivity, camaraderie and generosity. Craft entrepreneurs achieve fitting in not only by learning accepted norms, but also by performing strategic actions which allow them to temporarily adapt their conduct to meet the expectations of community members. Thus, this article exposes a largely concealed element of entrepreneurial practice. Furthermore, our findings reveal that embeddedness in craft communities can lead entrepreneurs to share their various resources with potential competitors to help one another and to perpetuate their respective industries. We find that craft entrepreneurs consider such supportive behaviour a social responsibility which is shared among community members and a task that is passed from one generation to the next. As such, this paper shows that, in certain contexts, collaboration and social value creation are embraced in response to community norms and expectations.

This article is structured as follows. In the next section, we review relevant literature on embeddedness in communities and social value creation. This is followed by a description of the conceptual framework (Bourdieu 1977, 1984, 1986) and research methods employed by this study. We then present our empirically grounded findings and discuss them in relation to current academic debates. Finally, we consider implications for theory and practice.

\section{Literature Review}

\subsection{Embeddedness in communities}

It has long been recognised that economic exchanges do not occur in separate economic spheres, but are embedded in ongoing systems of social relationships (Granovetter 1985; Uzzi 1997). Consequently, there has been sustained interested in examining the effects of embeddedness in different contexts on entrepreneurs (Jack and Anderson 2002; Shaw, Wilson, and Pret, Forthcoming; Smith and Stevens 2010). As prior research has 
'tended to gravitate more toward network embeddedness' (Kistruck and Beamish 2010, 738), comprehensive knowledge has been developed of the ways in which certain network structures can facilitate or impede entrepreneurial processes (Hite 2005; Ozcan and Eisenhardt 2009; Uzzi 1997). In comparison, there is limited understanding of the impacts of embeddedness in communities (Dana and Light 2011; McKeever, Jack, and Anderson 2015). A key reason for this is the realisation that 'different communities, at different times, will affect different entrepreneurial actors and processes in different ways' (Hindle 2010, 600), which suggests that research findings in one context are not readily generalisable to others. Thus, there have been repeated calls for research to investigate a wider range of community contexts to advance understanding of their specific characteristics and effects upon entrepreneurs (Jennings et al. 2013; Kwon, Heflin, and Ruef 2013).

Indeed, as Jennings et al. (2013) argue, entrepreneurship research has mostly focussed on exploring regional clusters (Lechner and Leyronas 2012; Tan, Shao, and Li 2013) and local communities (Korsgaard, Ferguson, and Gaddefors 2015; Parkinson, Howorth, and Southern, Forthcoming), rather than those bound by characteristics other than spatial proximity. These studies have highlighted that embeddedness in communities can provide entrepreneurs with access to local resources, such as knowledge, advice and financial support (Jack and Anderson 2002; Vershinina, Barrett, and Meyer 2011). Furthermore, it has been shown that entrepreneurial activities can foster community development (Johnstone and Lionais 2004; McKeever, Jack, and Anderson 2015) and that, in turn, communities can 'rally around and support entrepreneurial ventures to the benefit of the local areas' (Korsgaard, Ferguson, and Gaddefors 2015, 574). Research also reveals the existence of local boundaries to communities (Martí, Courpasson, and Dubard Barbosa 2013), which can lead to the exclusion of outsiders and which persist despite efforts of policy makers to promote openness (McKeever, Anderson, and Jack 2014). As such, communities can act as protective shelters which distance themselves through the development of individual patterns of interaction (Martí, Courpasson, and Dubard Barbosa 2013).

A primary reason for the existing focus on regional and local communities is the prevailing understanding of communities as geographically bound groups of actors (Jennings et al. 2013). In contrast, our conceptualisation extends beyond the geographic proximity of individuals and incorporates both economic and non-economic motivations for affiliation (i.e. a shared interest in crafts). This approach allows us to explore virtual and transnational communities, which have not received adequate attention to date (Drori, Honig, and 
Wright 2009; O'Mahony and Ferraro 2007), despite their increasing significance in the Digital Age (Jones et al. 2014). Our definition of communities also acknowledges that established cultural norms within groups can affect entrepreneurial actions (Khavul, Chavez, and Bruton 2013). While several studies highlight that incumbent social and moral obligations can constrain individual behaviours (Hindle 2010; Jack and Anderson 2002; Maurer and Ebers 2006), understanding of their diverse influences on entrepreneurs remains limited (Martí, Courpasson, and Dubard Barbosa 2013). This article addresses this gap by exploring the broader impacts of community norms and rules on entrepreneurial practices. Although scholars have proposed several theories about ways in which entrepreneurs may adapt their behaviours to meet the expectations of field members (De Clercq and Honig 2011; De Clercq and Voronov 2009; Fisher, Kotha, and Lahiri 2016), there is a lack of empirical research verifying these conceptual propositions (Stringfellow, Shaw, and Maclean 2014). This paper therefore makes an important contribution to the literature by empirically exploring how and why entrepreneurs adapt their behaviours to fit in with community norms and expectations. As will be shown, this article is able to both confirm several extant theories and shed new light into the 'hidden' practices of entrepreneurs. Furthermore, we find that, in seeking to conform to community norms, entrepreneurs may pursue social value creation.

\subsubsection{Community contexts in this study}

Given the centrality of context in shaping entrepreneurial processes (Aldrich and Fiol 1994; Mair, Martí, and Ventresca 2012), and especially its role in determining norms and expectations, it is important to discuss the community contexts in which entrepreneurs are embedded. While participating entrepreneurs all practise different crafts, there are several distinctive features common across these craft communities which differentiate them from other contexts and enable the identification of the craft sector as an entrepreneurial subculture (Bhagavatula et al. 2010; Kuhn and Galloway 2015). First, we found that craft communities are primarily virtual. While community members meet at local events, such as craft shows, their primary means of communication is through dedicated websites, which connect collectors and makers from around the globe. In other words, craft fields combine elements of local, virtual and transnational communities. As such, this article advances knowledge of embeddedness in these under-researched contexts (Drori, Honig, and Wright 2009; Jennings et al. 2013; O'Mahony and Ferraro 2007). The blending between producers and consumers is another 
distinguishing feature of craft communities. The same way that participants not only create, but also collect craft items, we discovered that many customers share an interest in learning how to craft products and maintain a hobbyist level of engagement. Thus, participants run workshops to help community members make their own products. Furthermore, we found that craft communities are close-knit despite being widely dispersed.

Regarding their embeddedness in local communities, participating entrepreneurs reside in rural villages. We chose to investigate rural locations (areas that 'fall outside of settlements with more than 10,000 resident population', as defined by Defra 2016, 1), because geographic isolation has been shown to facilitate the observation of social phenomena (Jack and Anderson 2002; Korsgaard, Ferguson, and Gaddefors 2015). Participants live and work in villages that are located within 2 hours of the English-Scottish border (less than 200 miles apart). The research sites are situated in former mining areas, which suffered severely when the mines' reserves were depleted. These regions further declined when the demand for labour reduced in other core industries, such as agriculture (Lang, Fink, and Kibler 2014). High unemployment levels, out-migration and economic downturn caused a number of social problems, including increased poverty and crime levels (Lee et al. 2011). These areas could therefore be described as 'deprived' or 'depleted' (Johnstone and Lionais 2004; McKeever, Jack, and Anderson 2015). However, circumstances are improving, mainly due to a recent resurgence of craft businesses, which have helped ameliorate the economic and social situation in these regions. Importantly, participants' influence on these areas goes beyond their business activities, as they get involved with their local communities and contribute to community welfare by engaging in voluntary work and community projects.

\subsection{Social value creation}

As Korsgaard and Anderson $(2011,135)$ argue, 'in entrepreneurship research there has been a strong tendency to see the value being created in entrepreneurship processes as solely economic.' Consequently, the concept of growth, which is a crucial aspect of entrepreneurship (Schumpeter 1942), is usually associated with economic expansion. However, community and social growth are similarly important for the advancement of society (Zahra and Wright 2016). Thus, there has been growing interest in investigating the pursuit of social value and social wealth creation by entrepreneurs (Mair and Martí 2006; Shaw and Carter 2007; Zahra et al. 2009). 
The most significant advances in understanding of this phenomenon have been developed by social entrepreneurship research (Chell, Nicolopoulou, and Karataş-Özkan 2010; Di Domenico, Haugh, and Tracey 2010). Despite the lack of a single definition of social entrepreneurship (Bacq and Janssen 2011; Nicholls 2010), most scholars agree that social entrepreneurs are driven by a desire to create social value (Dacin, Dacin, and Matear 2010; Smith and Stevens 2010). ${ }^{1}$ At the same time, it is acknowledged that the lines between commercial and social ventures are often blurred (McMullen and Warnick 2016; Stevens, Moray, and Bruneel 2015) and that firms increasingly adopt hybrid approaches (Battilana and Lee 2014; Pache and Santos 2013) and fuse 'value systems ... and agendas that traditionally were seen as incompatible' (Markman et al. 2016, 676). In other words, there is a growing recognition that entrepreneurs can be driven by a range of co-existing motivations (Wry and York, Forthcoming) and that entrepreneurs who are not usually associated with social entrepreneurship may still seek to create social value (Dacin, Dacin, and Matear 2010). This article adds to this emerging research by investigating craft entrepreneurs who would not traditionally be considered social entrepreneurs.

The desire to engage in social value creation is commonly understood as a result of compassion and personal conviction (Bacq and Alt 2016; Miller et al. 2012). However, recent empirical studies highlight the potential of context-related factors to stimulate social entrepreneurial activity (Lewis 2013; Tapsell and Woods 2010). This has led to repeated calls for research to explore the ways in which embeddedness in different contexts might promote socially oriented business practices (Dacin, Dacin, and Matear 2010; Shaw and de Bruin 2013). In particular, little is known about how and why social and moral obligations within community contexts may compel entrepreneurs to support collective social endeavours (de Bruin and Lewis 2015; Di Domenico, Tracey, and Haugh 2009). As Downing $(2005,196)$ argues, 'entrepreneurship, like the rest of social life, is a collaborative social achievement'; as such, social embeddedness can play an important role in the creation of social value and wealth (Bacq and Janssen 2011; Smith and Stevens 2010; Zahra and Wright 2016).

It has been suggested that collaboration among complementary organisations can generate greater social impact (Austin, Stevenson, and Wei-Skillern 2006; Zahra et al. 2009). Accordingly, an emerging body of research explores the potential of inter-organisational collaboration to facilitate social value creation (Akemu, Whiteman, and Kennedy 2016; Di Domenico, Tracey, and Haugh 2009). Smith and Stevens (2010, 587) suggest that a common 'exchange consists of the provision of various forms of capital for the creation of social value'. 
Still, there remains limited understanding of the particular resources that are exchanged among entrepreneurs to facilitate such processes (Barth et al. 2015). Di Domenico, Tracey, and Haugh $(2009,589)$ propose that social enterprises may draw upon the 'local knowledge, social capital and social legitimacy' of partners. Collaborative work has also been shown to provide social entrepreneurs with access to financial resources (Maclean, Harvey, and Gordon 2013) and tacit knowledge (Chalmers and Balan-Vnuk 2013). However, as prior research into business collaboration has mainly focussed on potential commercial benefits (Ahuja 2000; Phelps, Heidl, and Wadhwa 2012; Sorenson, Folker, and Brigham 2008), there are enduring gaps in understanding of how and why entrepreneurs collaborate to create social value.

This article seeks to address these gaps by exploring the collaboration and resource sharing practices of entrepreneurs who are embedded in communities that foster social value creation. In particular, we explore how and why embeddedness in community contexts might promote socially oriented business practices. This paper advances understanding of the wide range of resources that entrepreneurs share with community members for the common good. Furthermore, we reveal that community norms and expectations can, in fact, be a main cause for entrepreneurs to embrace social value creation. Thus, this article makes a valuable contribution to the social entrepreneurship literature.

\section{Conceptual framework: Bourdieu's theory of practice}

This article employs Bourdieu's $(1977,1984,1986)$ theory of practice as a conceptual framework to interpret the experiences of participants. Cognisant of alternative theories that have been used to explore entrepreneurial embeddedness, including structuration theory (Jack and Anderson 2002) and social network theory (Ozcan and Eisenhardt 2009), we selected Bourdieu's framework because of its conceptual clarity concerning the various resources entrepreneurs can access and share with community members (Karataş-Özkan 2011; Pret, Shaw, and Drakopoulou Dodd 2016), as well as for its appreciation of the influence of norms and conventions (habitus) within social fields (De Clercq and Honig 2011; Stringfellow, Shaw, and Maclean 2014). Furthermore, we found this framework well suited for explaining the behaviours of participating craft entrepreneurs. Figure 1 illustrates our interpretation of Bourdieu's theory of practice, which consists of the three interrelated concepts of field, habitus and capital. 


\section{-- Insert Figure 1 Here --}

According to Bourdieu (1984), actors vie for positions within dynamic social fields. Fields represent social spheres that unite groups of people (Battilana 2006; Spigel 2013); they range in form and size from nuclear families (Bourdieu 1996) to entire industries (De Clercq and Honig 2011). It has been shown that entrepreneurs can be part of several fields simultaneously (Terjesen and Elam 2009) and enter new fields if they possess the required amounts of capital (Shaw, Wilson, and Pret, Forthcoming). Thus, we propose that the concept of fields applies to communities, as we have defined them. ${ }^{2}$ Importantly, the concept accounts for groups based upon mutual interests, including craft makers and collectors, as well as for concurrent membership in multiple communities, such as both craft and rural communities, to take the example of participants in this study.

Bourdieu (1977) argues that the struggle for resources and influence within fields is primarily a subconscious process, which is directed by habitus (Anderson, Drakopoulou Dodd, and Jack 2010). Habitus represents the 'rules of the game ... that shape behaviors, and give meaning to them' (Drakopoulou Dodd et al. 2014, 636). Each field develops and maintains its own set of accepted rules and norms (habitus) and it is 'through routines of socialization and homophily [that] communities create and recreate a shared understanding of how their shared context operates' (McKeever, Anderson, and Jack 2014, 457). Habitus is therefore an essential element of every community and a feature that requires in-depth exploration to comprehend entrepreneurs' behaviours towards other embedded agents (Barrett and Vershinina, Forthcoming). However, the unique nature of every field's habitus is often overlooked in favour of presenting propositions (i.e. characterisations of community norms) that are generalisable to other contexts.

Each field develops not only a distinctive habitus, but also specific forms, volumes and distributions of capital (Nicolopoulou 2014). Bourdieu (1986) differentiates between four forms: (1) economic capital (financial and other business assets, such as materials and tools), (2) cultural capital (educational qualifications, personal dispositions and cultural goods, including craft pieces of artistic value), (3) social capital (networks and alliances, including guild memberships and its associated benefits) and (4) symbolic capital (status, reputation and recognitions, such as industry awards). While a large number of entrepreneurship studies investigate 
individual forms of capital (Gedajlovic et al. 2013; Marvel, Davis, and Sproul 2016), further research is required that explores all four forms together (Pret, Shaw, and Drakopoulou Dodd 2016). It has been shown that access to a range of capitals is essential for success, particularly within the creative and cultural industries (Jones et al. 2016; Shaw, Wilson, and Pret, Forthcoming), reinforcing the concept's relevance to this study.

Finally, Bourdieu (1986) argues that human behaviour can only be understood if research goes beyond examining economic motivations. Throughout his writings, Bourdieu $(1977,1984)$ emphasises the importance of exploring the social worlds and the interconnections between agents who seek to effect their environments and are simultaneously shaped by them. It is this appreciation of the influence of context on individuals, which led us to select Bourdieu's theory of practice as our theoretical framework for interpreting the experiences of participants.

\section{Methods}

\subsection{Industry selection}

As discussed by Glynn and Lounsbury (2005), cultural industries are compelling sites of study for scholars interested in the dynamics between individual practices and the norms and expectations within social fields. Prior research reveals that the cultural sector is comprised of a large range of interconnected communities (McLeod, O'Donohoe, and Townley 2011), which are influenced by various 'specialized institutions such as schools and universities ... labor unions [and] trade associations' (Scott 2006, 8). Furthermore, cultural industries make an important contribution to national economies and 'account for 1,600 billion dollars of commerce annually, representing $3.4 \%$ of global national product' (Le Breton-Miller and Miller 2015, 1354). Thus, the sector merits exploration as a central institution in post-modern society. Within the cultural sector, we chose to explore the perspectives of craft entrepreneurs because prior research has demonstrated their ability to respond to constraints with creative solutions (Al-Dajani et al. 2015; Bhagavatula et al. 2010; Pret, Shaw, and Drakopoulou Dodd 2016). Additionally, the lead author has prior experience as a craft professional, which helped in building rapport with participants and encouraged them to share their stories more openly. 


\subsection{Research design}

Responding to the call for more methodological and paradigmatic diversity (Shaw and de Bruin 2013; Shepherd 2015), we chose to conduct an interpretative phenomenological analysis (Cope 2011; Smith, Flowers, and Larkin 2009). Interpretivist perspectives and phenomenological approaches are gradually gaining popularity within entrepreneurship research (Lewis 2015; Parkinson and Howorth 2008; Pret, Shaw, and Drakopoulou Dodd 2016), because of their capacity for 'developing both new theoretical constructs and enhancing the potency of existing ones, bridging the gap between real-life occurrences and theoretical concepts' (Cope 2011, 610). The primary objective of phenomenological research is to examine the lived experiences of participants and to gain deep understandings of their personal and social worlds (Berglund 2007; Sandberg 2000). As such, phenomenological approaches are well suited for in-depth investigations of the ways in which entrepreneurs react to the different norms and expectations that exist in the social contexts in which they are embedded.

\subsection{Participant selection}

This research is part of a wider study investigating entrepreneurship in craft industries. As such, participants were not selected based on their interest in or pursuit of social objectives. Rather, their collaboration activities and social value creation were significant findings of our study, as discussed below. Following Tregear $(2005,2)$, we define craft makers as individuals who 'possess certain technical skills derived from experience or apprenticeship that set them apart from other types of manual worker[s]'. In order to identify craft entrepreneurs in particular, we drew upon Fillis (2004), who presents four distinct profiles of craft makers. This typology allowed us to distinguish between craft lifestylers, idealists, late developers and entrepreneurs. According to Fillis $(2004,71)$, a craft entrepreneur 'is willing to take risks and recognizes the importance of developing a customer base ... [and] exhibits ambition for growth' Thus, in choosing our sample, we sought to identify craft owner-mangers who embodied these traits, practised craft as their primary profession and operated their businesses from a dedicated studio or workshop. We first advertised our proposed study to makers in the UK through craft business networks. Our call for participants generated a considerable amount of interest, which allowed us to meet with several candidates and evaluate whether they fulfilled our inclusion criteria. As suggested by Smith (2004), we selected 10 participants, using purposeful sampling to include a range of 
experiences (Patton 2015). Appendix 1 provides background information on participating entrepreneurs and illustrates the broad range of crafts included in this article, from contemporary artistic teddy bear making to the more traditional basket weaving and pottery making.

\subsection{Data collection and analysis}

Heeding the call for more longitudinal entrepreneurship research (McMullen and Dimov 2013), we collected data over 14 months (starting in February 2013), primarily through three rounds of interviews, which were conducted with participants in intervals of six to seven months. As suggested by Patton (2015), we interviewed participants in their homes or on their work premises, outside of opening hours and using colloquial language. The first interviews were unstructured to gain a deep understanding of the backgrounds and perspectives of participants (Cope 2005). It was during these initial discussions that we realised collaboration and resource sharing were both common and significant practices within craft communities. Thus, we employed a semi-structured format in subsequent interviews to investigate these emerging themes (Berglund 2007). The 30 interviews, each of which lasted between one and three hours, provided us with substantial quantities of rich empirical data (over 750 single-spaced transcript pages in total). We also collected observational data at craft shows and in the studios of participants, taking note of their working practices and interactions with community members (McKeever, Anderson, and Jack 2014). In addition, we accessed other sources of information, including online forum discussions, blogs and social media platforms to which participants contribute, to gain a deeper understanding of the contexts in which participants are embedded (Lewis 2015). However, it should be noted that interviews represent our primary source of data, as they provided the deepest insights into the perspectives of participants (Pret, Shaw, and Drakopoulou Dodd 2016).

We recorded and transcribed interviews verbatim, which enabled us to systematically analyse our raw data. The collection and analysis of data occurred simultaneously, following the conventions of interpretative phenomenological analysis (Cope 2011; Smith, Flowers, and Larkin 2009). This process involved performing the five steps described in Table 1 . We repeated these steps after each round of interviews. During the analysis process, it became apparent that our data would benefit from the application of a conceptual framework. We decided to employ Bourdieu's $(1977,1984,1986)$ theory of practice, because we found that his concepts of (a) 
field, (b) habitus, and (c) capital could help explain our emerging findings concerning (a) communities, (b) norms and expectations, and (c) resource sharing practices.

-- Insert Table 1 Here --

\subsection{Validity and reliability criteria}

It has been argued that the quality of phenomenological research cannot be evaluated according to traditional positivist criteria, such as generalisability and objectivity (Berglund 2015). Cognisant of alternative techniques to demonstrate the validity and reliability of interpretivist research (Leitch, Hill, and Harrison 2010), we chose to adopt Sandberg's (2005) well-established approach, which advocates the use of four criteria: pragmatic, communicative and transgressive validity and reliability as interpretive awareness. First, we asked participants probing questions to verify our interpretations of their experiences and to achieve pragmatic validity (Kvale 1989). This process provided participants with opportunities to clarify their positions and allowed us to correct any discrepancies in understanding (Sandberg 2000). Second, we asked open-ended questions to allow participants to give detailed accounts of their experiences. This helped us obtain consistent interpretations and achieve communicative validity (Kvale 1989). Third, we explored the differences between the descriptions of individual participants to account for the complex and personal nature of their lived experiences and to ensure transgressive validity (Lather 1993). Finally, we addressed the subjectivity that arises from prior knowledge of a topic and from close relationships with participants to establish reliability as interpretive awareness (Sandberg 2000). Specifically, we sought to hold back any preconceptions regarding the effects of entrepreneurial embeddedness and checked continuously that there were no alternative conceptualisations which were better suited to explain the emerging themes we identified.

\section{Discussion of findings}

In this discussion of our results, we explore the influences of craft community embeddedness on entrepreneurs. We address our first research question regarding how and why entrepreneurs adapt their behaviours to fit in with community norms and expectations, and then our second research question, how and why embeddedness in community contexts can promote socially oriented business practices. Adopting Cope's 
(2011) approach, empirical evidence related to each of the two research questions is presented, analysed and interpreted, highlighting the theoretical contributions of this article.

\subsection{Fitting in with norms and expectations}

This section illustrates the critical nature of conforming to the norms and rules (habitus) of communities and how this affects the behaviours of craft entrepreneurs. Our analysis of data revealed that, to be accepted within their craft communities, entrepreneurs must meet certain expectations. As 'it is such a specific niche product' (Alice) that participants produce for 'a very small, but very well populated world' (Georgia) of customers, it is essential for them to become and remain members of their respective craft communities. Accordingly, we found that participants observe a range of established conventions, as shown in Table 2 .

\section{-- Insert Table 2 Here --}

We discovered that participants who studied their respective crafts at college or university were made aware of existing norms by teachers and peers, while lateral entrants engaged in a mixture of experimentation and relational learning (particularly at shows and exhibitions) to gain an understanding of established norms and conventions. As Irene highlights: 'It's important ... to know what other people [peers] do ... finding out how they operate ... how each individual [behaves], what they do'. Participants emphasise that this learning process is time-consuming, but that they consider it essential in order to build legitimacy for their operations. As Faith explains, 'because I've done it for several years now ... I know what's expected'. Not only do craft entrepreneurs need to learn the 'rules of the game'; they also have to 'serve their time', meaning they have to be seen to comply with existing norms over time to gain acceptance. In Debra's words, 'people want to see you out there for a few years ... so yeah, it's just having the patience'.

Table 2 highlights that once an entrepreneur is accepted within the craft community, there appears to be both a sense and an expectation of camaraderie. This fellowship brings with it a range of benefits, including moral support and the generosity of community members. As discussed in the following section, existing norms encourage the sharing of resources and collaboration among community members. However, the expectation that entrepreneurs demonstrate their solidarity can also impose obligations, as described by Cheryl: 
It is a very small community so you do have to be careful not to annoy people ... for me to not do a Scottish event would be kind of insulting, I think, so yeah, if for some reason I couldn't do it [the show] ... it might make things a little awkward.

Indeed, when community members fail to meet the expectations of others, they become the subjects of gossip. Beth explains that: 'it's a very small community and it's kind of human nature ... so if somebody does something wrong, everybody hears about it'. In other words, fear of being punished through becoming the subjects of gossip leads entrepreneurs to comply with community norms. Gossip within these fields therefore acts as a social control mechanism, enforcing community members' compliance with expectations.

As participants seek to fit in with the standards of their respective craft communities, however, they often experience a sense of standing out from accepted conventions of other fields, such as the rural communities in which they live. Both Beth and Debra use the example of dress to illustrate the tensions between conforming to norms within different fields:

If you're involved in a creative field ... there is an expectation that you're going to look interesting ... If I looked really normal and ... had my natural hair colour and a really normal hair cut ... I think people would be a bit disappointed ... 'cos there is this expectation that you're going to be quirky or different. (Beth)

Some people can say 'I bet you are a creative person because you dress in a certain way' ... I found when I first moved to the village, there was lots of people saying, 'Gosh all those [colourful] tights ... what in earth is that?' (Debra)

In such instances, craft entrepreneurs prioritise one field over another in choosing which conventions to adopt. Participants also stand out from accepted norms through other, innate attributes, such as a different place of birth or accent. Georgia reveals that 'a lot of people up here ... they think I'm posh. ... I just have a southern accent, but in the North East of England, you know, the way I talk, it's sometimes a big handicap'.

-- Insert Table 3 Here --

As illustrated in Table 3, we discovered that participants employ a range of strategies, such as performing, pretending and concealing, to facilitate fitting in with accepted norms. Rather than permanently aligning all of their practices, we found that craft entrepreneurs often change their behaviours temporarily 
according to field-specific expectations. As Alice puts it, 'when you are at shows you've got to really be at your best ... it's called "play the game"'. It was interesting to observe participants conceal certain traits and switch between different manners of acting depending upon the groups of people with whom they interacted. However, we also discovered that there are limits to the abilities of craft entrepreneurs to join fields by adopting normative behaviours. For example, as Irene explains,

in the North East the families are very tight ... it comes through the sort of, the clan village system ... there is a community network of inter-social family networks, they are so closed, they don't need anybody else. It sounds very strange, but they don't need you, an outsider ... if they had met you in the street they would be perfectly polite and friendly but you would never get close to them.

In other words, while strategic changes of behaviour can help entrepreneurs fit into social fields, some communities are too exclusive to join or their expectations are too high to meet.

\subsubsection{Analysis and interpretation}

There are a number of ways in which our empirical findings contribute to current theoretical debates regarding the role of habitus within entrepreneurial sub-cultures, as illustrated by the craft entrepreneurs within this study. First, our findings underscore the necessity for entrepreneurs to discover and comply with the conventions in their fields (Fisher, Kotha, and Lahiri 2016; Khavul, Chavez, and Bruton 2013); however, we also extend existing knowledge of the ways in which field-specific norms (habitus) affect the practices of entrepreneurs (De Clercq and Honig 2011; McKeever, Anderson, and Jack 2014). Within this community context, we reveal that entrepreneurs are expected to exhibit high levels of positivity, camaraderie and generosity. While such community contexts appear to encourage the inclusion of new members, they discourage debate about existing norms (habitus) and the evolution of established practices (Parkinson, Howorth, and Southern, Forthcoming). Hence, incomers are welcomed only if they conform to and abide by existing rules (habitus). When craft entrepreneurs fail to conform to community rules, they employ a range of strategies (e.g. pretending, concealing and performing) to disguise their conduct. As such, our findings contrast with several theories proposed by conceptual research. Rather than seeking to effect change within the community (Battilana 2006) or acquiring all the cultural resources personally required to fit in with existing norms (De Clercq and 
Voronov 2009; Lounsbury and Glynn 2001), we find that craft entrepreneurs circumvent problems by concealing non-conforming traits and practices. Thus, this article reveals more complex, perhaps less favourable, practices undertaken by entrepreneurs than commonly portrayed in the literature (Calás, Smircich, and Bourne 2009).

Second, our findings provide new insights into the habituation process (Anderson, Drakopoulou Dodd, and Jack 2010; Khavul, Chavez, and Bruton 2013), and advance understanding of the impact of embeddedness in multiple contexts (Welter 2011). We discover that the habituation process of learning to comply with fieldspecific conventions is both demanding and time-consuming, and that craft entrepreneurs rely on the support of community members to learn how to achieve the necessary degree of conformity (McLeod, O'Donohoe, and Townley 2011). Advancing existing knowledge, we also reveal that there are limits to the behaviour-adaptation abilities of entrepreneurs. Lack of kinship within a place, for instance, can prevent access to certain fields. Furthermore, we reveal that embeddedness within multiple fields can cause difficulties for entrepreneurs: by trying to fit in with the norms of one field, they may simultaneously stand out from those of another field (Battilana 2006; De Clercq and Voronov 2009). We find that craft entrepreneurs weigh the costs and benefits of fitting in and, when necessary, prioritise one community over another.

Third, our findings demonstrate that the obligations of field-specific conventions can impede entrepreneurial processes. While prior studies acknowledge the constraints imposed by community embeddedness (Hindle 2010; Uzzi 1997), these studies have focussed on the influence of structural dimensions, such as the close-knit nature of communities and its potentially negative effects on information flow (Kwon, Heflin, and Ruef 2013; Tan, Shao, and Li 2013). In contrast, our findings highlight the importance of behavioural dimensions. Field specific expectations of camaraderie can restrict entrepreneurial actions by demanding conformity. Should craft entrepreneurs fail to adequately exhibit their solidarity, they can be punished by a 'collective sanction for undesired behavior' (Rooks, Klyver, and Sserwanga 2016, 113) delivered through gossip. Such punishments are harmful to the business practices of entrepreneurs, as they lead to animosity among field members. The fear of becoming the subjects of gossip leads participants to adjust their behaviours. Further extending existing knowledge of habitus, we find that entrepreneurs are driven to comply with field conventions both for the benefits this guarantees and to avoid community penalties. 


\subsection{Collaboration and sharing of resources}

The need to conform to field conventions can greatly affect the practices of entrepreneurs. Instead of engaging in 'traditional' business activities, such as competing for resources and customers to maximise profits (Knight 1921; Schumpeter 1942), this article reveals that, within craft communities, entrepreneurs are expected to collaborate and share their various forms of capital in a manner that promotes socially oriented business practices. For example, Irene explains that despite 'two very bad experiences in terms of time wasting and no feedback whatsoever ... there is an expectation that you will help and demonstrate what you can do'. She continues to support others because 'we [makers] have always been sort of swapping ideas. I [have] helped several ... people develop their products'. Jacob, who is a new member of his craft community, makes a similar observation: 'we all try and help each other out ... that's the impression I get'.

We find that craft entrepreneurs collaborate in a number of ways. For example, as Cheryl explains, they become involved in collaborative initiatives: 'she and I are part of the collective that will do ... the craft fairs in the winter ... so we're gonna work together as collaborative partners'. Furthermore, craft entrepreneurs develop joint products and exhibitions. In Georgia's words, 'I've been asked to collaborate in quite a few ... exhibitions in the future, which I'm really flattered about ... It will be interesting to collaborate on a theme that we work on together'. Most importantly, participants provide each other with free resources, as described by Beth:

I had offered what's called "yarn support" to her, so if a designer wants to knit a pattern and wants to use a specific yarn, they'll get in touch with the person that makes the yarn and ask for yarn support, which means that you'd give them the yarn for free in exchange for it being featured in the pattern, so ... I get asked quite a lot if I'll provide yarn support.

-- Insert Table 4 Here --

As shown in Table 4, there are several reasons why craft entrepreneurs collaborate and share their various forms of capital. While these motivations are personal and differ among participants, they also represent principals to which craft makers are expected to adhere. For example, participants demonstrate a deep commitment to 'perpetuating the industry ... keeping up an interest or getting more people into it' (Alice). Additionally, they seek to ensure that skills get passed from one generation to the next and that a genuine interest in arts and crafts is sustained. Though sympathetic with this aim, Cheryl shares that ' $I$ think there is an 
expectation that, because you make art, you know, keeping it alive ... comes before your business'. While they value the help received from community members, we find that participants do not usually expect reciprocity. As Debra recounts, 'I helped him out by explaining what you can do [with the material] - if I don't get any work from it, that's fine'. Although the sharing of resources can help craft entrepreneurs develop their networks (social capital) and maintain a positive reputation (symbolic capital), these are not the primary reasons for participants to engage in such practices. ${ }^{3}$ Instead, we find that craft entrepreneurs consider peer support and industry preservation a social responsibility, which they become aware of during the habitation process and which they assume when seeking to fit in with the conventions of craft communities (see Table 2). In Georgia's words, 'we kind of share the responsibility'.

Even when the threat to their businesses would appear high, due to the potential for copying, participants still help others. As shown in Table 5, this article reveals that there are several reasons for craft entrepreneurs to accept such risks. Because their individual styles are so closely linked to their personalities and dependent upon their individual skill-sets (cultural capital), participants believe that it would be difficult to copy their products. Additionally, there appears to be 'an unwritten rule of ... not copying people's ideas' (Helen). If craft makers are found to be plagiarising others' ideas, they are ostracised from the community, as happened to a maker who copied Georgia's work: 'everybody became aware of that person'.

\section{-- Insert Table 5 Here --}

We discovered that craft entrepreneurs share and freely give a range of resources, including economic, cultural, social and symbolic capital. First, concerning their economic capital, several participants made statements similar to Jacob:

I have kind of an unwritten policy that ... I try to spend [money] ... on buying something from another crafter, because there is a huge amount of value to handcrafted stuff and ... because it [craft work] needs to be encouraged.

Participants also engage in other forms of charitable giving. Cheryl reports, 'I have done craft fairs where it's for charity', and Jacob recounts that, 'in the village ... there was a charity auction and I gave ... charity lessons [in pottery]'. Similarly, Irene describes, 'I've volunteered to do ... things in the [community space] ... I showed 
them how to do it [making books]'. In other words, craft entrepreneurs are willing to donate products and time (which they would otherwise spend crafting products) to help their communities.

Second, the exchange of cultural capital appears commonly practiced. Craft entrepreneurs share their knowledge and engage in co-creation processes with peers both online and at shows and guild meetings. As Faith explains, 'everybody was swapping ideas and it was just everybody's ideas coming together and culminating'. Similarly, Ethan expresses, 'you learn a lot by talking to people [peers] and ... they can give you good ideas for ways to expand'. In Irene's words, 'you feed off each other, it's in the ether ... it's just creative thinking ... talk, banter, just bandying ideas about'. As such, we find that craft entrepreneurs 'like to work collaboratively' (Cheryl) to help each other gain creative inspiration, to exchange knowledge and to share skills.

Third, the sharing of social capital is apparent as participants both act as relationship brokers and benefit from those who make introductions between community members, such as suppliers and makers. As Irene describes, 'you pass on contacts, networks, that kind of thing.' More surprisingly, we find that it is also a common practice to pass on customer contacts. As Beth explains, customers 'will have a specific pattern in mind and ... a lot of the time ... it's not something that I have [in stock], so I'm happy to refer them to someone else'. Accordingly, Georgia expresses that 'I think being part of a creative community in general is beneficial, because we're all kind of encouraging people to go see everything else as well.'

Finally, we find that established craft entrepreneurs share their symbolic capital by associating with less well-known peers. For example, Beth reveals that her yarn is regularly recommended by a famous community member who will 'launch a pattern and within sort of weeks there'll be thousands of people that are making it, so the ...potential of being linked to someone like that is amazing'. Established makers also use their reputation and standing to raise awareness of their communities. This can be achieved by hosting craft exhibitions, the reasons for which Alice explains as 'For our little, small world, to try and expand it a wee bit more ... to get more people interested in what the artist bear is, as opposed to just collecting toy bears'. Having observed the preparation and delivery of the event, it became apparent that financial objectives are not a motivating factor for its creation. Rather, we discovered that craft entrepreneurs engage in such activities to support both newcomers and the community as a whole. 


\subsubsection{Analysis and interpretation}

Using Bourdieu's theory of practice as our theoretical lens, this article sheds new light on the interconnections between entrepreneurs who seek to influence their environments and are simultaneously shaped by them. We show that embeddedness in certain contexts, such as craft communities, leads entrepreneurs to share their various forms of capital and, moreover, to collaborate in pursuit of creating social value (Korsgaard and Anderson 2011; Smith and Stevens 2010). Craft entrepreneurs provide regular and generous help to community members, sharing their capital in order to perpetuate their respective industries and to sustain a genuine interest in hand-crafted products. Participants consider such supportive behaviour to be a social responsibility and a task that is passed from one generation to the next. Thus, their behaviours contrast with the prevailing neo-classical, market-driven perspective, which permeates entrepreneurship research (Knight 1921; Schumpeter 1942), and highlight the value of the Bourdieusian approach of looking beyond economic motivations.

While the potential of entrepreneurs to benefit society has long been established by social entrepreneurship research (Mair and Martí 2006; Zahra et al. 2009), the creation of social value is usually understood as an outcome of compassion and personal conviction (Bacq and Alt 2016; Miller et al. 2012). This article provides new insights into social entrepreneurship by revealing that, in certain contexts and among certain entrepreneurial sub-cultures, collaboration and social value creation are also embraced in response to community norms and expectations. As such, our findings add to the emerging body of research that highlights the influence of contextual factors on social entrepreneurial activities (de Bruin and Lewis 2015; Lewis 2013; Tapsell and Woods 2010). Furthermore, we show that entrepreneurs who do not identify as social entrepreneurs and who are involved in an industry not usually associated with social entrepreneurship (Dacin, Dacin, and Matear 2010), may still dedicate significant efforts to social value creation. ${ }^{4}$

As Nicolopoulou (2014) argues, the protection of intellectual property among cooperating businesses is of major significance in most industries. In comparison, this article reveals that craft entrepreneurs are relatively unconcerned about the risk of plagiarism. This is due to the individual nature of their products as well as to the norms and conventions (habitus) in their fields, which sanction dishonest members through loss of reputation and exclusion from the community (Dana and Light 2011; Khavul, Chavez, and Bruton 2013; Maurer and Ebers 2006). This article therefore demonstrates that unwritten rules of behaviour within communities can also have a 
liberating impact on the practices of entrepreneurs, which further promotes collaboration and value creation. When entrepreneurs feel safe sharing ideas and resources, it can become almost second nature. This finding contrasts with research that highlights the negative impacts of community norms and conventions on entrepreneurial practices (Parkinson, Howorth, and Southern, Forthcoming).

Finally, this article advances understanding of the various resources that are exchanged among collaborating entrepreneurs in their efforts to create social value (Barth et al. 2015; Di Domenico, Tracey, and Haugh 2009). While prior research into business collaboration has mainly focused on the exchange of knowledge among network partners (Ahuja 2000; Phelps, Heidl, and Wadhwa 2012), our findings reveal that embeddedness in craft communities can lead entrepreneurs to engage in a much broader sharing of various forms of capital (Smith and Stevens 2010). Specifically, we show that craft entrepreneurs are willing to freely give time and money (economic capital), provide creative inspiration and share skills (cultural capital), pass on supplier and customer contacts (social capital) and use their reputation to promote fellow community members (symbolic capital). Thus, this article highlights the need to take into account a broad range of capitals to gain a deeper understanding of the behaviours and contributions of entrepreneurs (Karataş-Özkan 2011; Nicolopoulou 2014). We also provide new evidence with regard to the mutability and convertibility of different forms of capital (Pret, Shaw, and Drakopoulou Dodd 2016; Vershinina, Barrett, and Meyer 2011), by demonstrating that capital conversion processes can involve several field members and be performed specifically to benefit others.

\section{Conclusion}

Although there is both an increasing recognition of the influence of different contexts on entrepreneurial processes (Aldrich and Fiol 1994; Johannisson, Ramírez-Pasillas, and Karlsson 2002; Mair, Martí, and Ventresca 2012) and a growing body of context-focused entrepreneurship research (Welter 2011; Zahra, Wright, and Abdelgawad 2014), there remain enduring gaps in knowledge of the effects of embeddedness within divergent communities (Hindle 2010; Jennings et al. 2013; Martí, Courpasson, and Dubard Barbosa 2013). In particular, little is known about how and why social and moral obligations within community contexts may compel entrepreneurs to engage in collaboration and social value creation (de Bruin and Lewis 2015; Di Domenico, Tracey, and Haugh 2009). Furthermore, understanding is limited of how entrepreneurs manage to fit in with the 
norms and expectations of the communities in which they are embedded (De Clercq and Voronov 2009; Maurer and Ebers 2006). Based on the lived experiences of craft entrepreneurs, this article addresses these gaps and advances knowledge in a number of ways.

First, this article illustrates that embeddedness in certain fields, such as craft communities, can lead entrepreneurs to experience a sense of fellowship and camaraderie, instead of a desire to gain advantage over other field members. Thus, our findings challenge prevalent depictions of entrepreneurs as 'lone heroes' who are primarily driven by competition and profit (Knight 1921; Schumpeter 1942). Rather, we reveal that craft entrepreneurs collaborate and share their various forms of capital with community members in pursuit of creating social value (Mair and Martí 2006; Smith and Stevens 2010). As participants neither identify as social entrepreneurs, nor operate businesses that are usually associated with social entrepreneurship, the findings of our study suggest that social entrepreneurial goals and practices may be more widespread than is currently assumed. Indeed, we argue that social entrepreneurship research currently overlooks an important group of entrepreneurs: those who create social value by supporting their peers and freely sharing their various resources. While their motivations for creating this social value may be limited to positively impacting their individual community context (i.e. the craft community), not only is this a social good in itself, but the resultant outcomes for the wider local area further compound the social value created. Accordingly, we propose that future studies explore the role of social value creation in contexts not traditionally associated with social entrepreneurship.

Second, this article shows that collaboration and social value creation can be embraced in response to community norms and expectations. As such, our findings support the view that social entrepreneurial behaviour cannot be fully understood without considering the contexts in which entrepreneurs are embedded (de Bruin and Lewis 2015; Shaw and de Bruin 2013). Furthermore, this article advances understanding of the various resources that entrepreneurs share with community members for the common good. In addition to providing financial resources (Maclean, Harvey, and Gordon 2013) and knowledge (Chalmers and Balan-Vnuk 2013), we reveal that craft entrepreneurs share their economic, cultural, social and symbolic capital. Accordingly, we suggest that future studies take this broader range of capitals into account when seeking to identify the ways in which entrepreneurs contribute to both their communities and society at large. 
This article confirms the relevance of Bourdieu's conceptual framework to the study of entrepreneurial practices (De Clercq and Voronov 2009; Karataş-Özkan 2011). We provide a range of examples that demonstrate the applicability of the concepts of field, habitus and capital to investigations of the various dimensions of context (Drakopoulou Dodd, Pret, and Shaw 2016; Özbilgin and Tatli 2005). While Bourdieu (1977, 1984, 1986) argues that human behaviour is mostly characterised by struggles for resources and influence within social fields, the findings of our study suggest that, in certain community contexts, field-specific rules (habitus) can override conventional market-driven logics. Thus, this article highlights the need for research to employ the full complement of Bourdieusian concepts to fully understand the inner logics of different social fields.

This paper also reveals ways in which craft entrepreneurs adapt their behaviours to fit into different community contexts (De Clercq and Voronov 2009; Lounsbury and Glynn 2001). We show that craft entrepreneurs perform a range of strategic actions (e.g. pretending, concealing and performing) that allow them to temporarily change their conduct and to conceal undesirable traits when their usual practices fail to meet the expectations of community members. As such, this article highlights a hidden element of entrepreneurial practice, which is often disregarded when portraying entrepreneurs in a more favourable light (Calás, Smircich, and Bourne 2009). We contend that further investigations into such concealed practices could greatly advance understanding of the real-life behaviours of entrepreneurs.

Our findings demonstrate that the habituation process of learning to comply with field-specific norms can be time-consuming (Anderson, Drakopoulou Dodd, and Jack 2010; Khavul, Chavez, and Bruton 2013) and that craft entrepreneurs rely on the support of community members to achieve this objective. However, we also discover that there are limits to the abilities of entrepreneurs to enter new fields by adapting their behaviours. Furthermore, our findings indicate that embeddedness within multiple fields can cause difficulties for entrepreneurs: by trying to comply with the norms of one context, they may simultaneously transgress in another. Thus, we encourage future research into the difficulties and opportunities that can arise from embeddedness in overlapping fields.

The detailed descriptions provided in this article are valuable, as they advance knowledge and add empirical weight to existing conceptual discussions (Battilana 2006; De Clercq and Voronov 2009; Fisher, Kotha, and Lahiri 2016). As McKeever, Jack, and Anderson (2015, 62) note, 'although social theorising may tell 
us much about macro changes, it is only by analysing the actions of the entrepreneurs, their realities and social context, that further understanding of the breadth of the entrepreneurial process can be developed'. Our phenomenological approach was crucial for gaining the deep insights required to provide such a comprehensive account of the ways in which embeddedness in craft communities influences the behaviours of entrepreneurs. It enabled us to present a realistic picture of entrepreneurs' actions, highlighting both their virtuous behaviours, including collaboration and social value creation, and their more devious practices, such as pretending to be something they are not.

It is, of course, important to emphasise that our phenomenological approach and small sample size constrain generalisation of our results to wider populations (Berglund 2015; Cope 2011). Thus, we suggest that future studies compare our findings to other contexts to help advance understanding of these intriguing facets of entrepreneurial practices. While craft communities may be a 'special case', we would expect that there might be other, currently overlooked contexts in which collaboration and social value creation are encouraged, embraced and perhaps also expected as community conventions.

On a practical note, a major benefit of adopting a phenomenological research approach is that proximity to participants offers the ability to provide practical advice based on their lived experiences (Berglund 2007). Heeding the call for 'more practical knowledge - knowledge that is useful to entrepreneurs, policy makers, educators, and scholars' (Kenworthy and McMullan 2013, 983), this article produces several recommendations that should help entrepreneurs develop their businesses, especially within craft communities. Entrepreneurs who consider starting a venture in a community context should allocate time to learn accepted norms, and be aware of the potential harm that can result from disregarding existing conventions and of the sanctions that can be imposed, such as being ostracised from the community. Employing strategies that help conceal inappropriate traits can help entrepreneurs meet the expectations of divergent communities. Furthermore, we suggest that craft entrepreneurs approach peers for help, as collaboration and resource sharing are common practices in many craft communities. Community members may be willing to share a much broader range of resources than is widely believed. Nascent entrepreneurs should also be aware that international, online communities can consist of closeknit networks of people. Being seen to conform to established norms can therefore help entrepreneurs gain acceptance. However, once accepted within a craft community, there appears to be a sense, as well as an 
expectation, of camaraderie among craft makers. This fellowship can support entrepreneurs by discouraging unethical behaviours, such as product plagiarism, but it can also create obligations, including the need to stay positive and to attend community events.

For policy-makers, we recommend becoming more aware of the impact of community members on entrepreneurial processes. As long as our focus is fixed on the individual, we may fail to appreciate the potential of community members to influence and foster entrepreneurial activities. Furthermore, it is important to acknowledge the social value that craft entrepreneurs create through their community engagement. If craft makers were unwilling to provide regular and generous help to community members, it is questionable whether such a range of crafts and widespread, genuine interest in hand-crafted products could be sustained over time.

\section{Notes}

1. According to Peredo and McLean $(2006,59)$ 'the social entrepreneur aims in some way to increase "social value," i.e. to contribute to the welfare or well being in a given human community".

2. Accordingly, we use the terms community and field interchangeably in this article.

3. We asked participants probing questions (directly and indirectly) about their motivations on several occasions, both on-tape and during informal conversations, to verify our interpretations of their behaviours.

4. Participants identify mostly as craft business owners. However, this is mainly due to the picture painted and perpetuated by the media of 'entrepreneurs as autonomous and self-made heroes' (Karataş-Özkan 2011, 884). As explained in the methods section, we classify participants as entrepreneurs because their practices correspond with the concept of craft entrepreneurs developed by Fillis (2004).

\section{References}

Ahuja, Gautam. 2000. "Collaboration Networks, Structural Holes, and Innovation: A Longitudinal Study." Administrative Science Quarterly 45 (3): 425-455. doi:10.2307/2667105.

Al-Dajani, Haya, Sara Carter, Eleanor Shaw, and Susan Marlow. 2015. "Entrepreneurship among the Displaced and Dispossessed: Exploring the Limits of Emancipatory Entrepreneuring." British Journal of Management 26 (4): 713-730. doi:10.1111/1467-8551.12119. 
Akemu, Ona, Gail Whiteman, and Steve Kennedy. 2016. "Social Enterprise Emergence from Social Movement Activism: The Fairphone Case." Journal of Management Studies 53 (5): 846-877. doi:10.1111/joms.12208. Aldrich, Howard E., and C. Marlene Fiol. 1994. "Fools Rush in? The Institutional Context of Industry Creation." Academy of Management Review 19 (4): 645-670. doi:10.5465/amr.1994.9412190214.

Anderson, Alistair R., Sarah Drakopoulou Dodd, and Sarah L. Jack. 2010. "Network practices and entrepreneurial growth." Scandinavian Journal of Management 26 (2): 121-133. doi:10.1016/j.scaman.2010.01.005.

Austin, James, Howard Stevenson, and Jane Wei-Skillern. 2006. "Social and Commercial Entrepreneurship: Same, Different, or Both?" Entrepreneurship Theory and Practice 30 (1): 1-22. doi:10.1111/j.15406520.2006.00107.x.

Bacq, Sophie, and Elisa Alt. 2016. Being Valued or Feeling Capable? Explaining Why Empathy Inspires Social Entrepreneurial Intentions. Paper presented at the Academy of Management Annual Meeting, Anaheim, CA, August 5-9.

Bacq, Sophie, and Frank Janssen. 2011. "The multiple faces of social entrepreneurship: A review of definitional issues based on geographical and thematic criteria." Entrepreneurship and Regional Development 23 (56): 373-403. doi:10.1080/08985626.2011.577242.

Barrett, Rowena, and Natalia Vershinina. Forthcoming. "Intersectionality of Ethnic and Entrepreneurial Identities: A Study of Post-War Polish Entrepreneurs in an English City." Journal of Small Business Management. doi:10.1111/jsbm.12246.

Barth, Sharine, Jo Barraket, Belinda Luke, and Juliana McLaughlin. 2015. "Acquaintance or partner? Social economy organizations, institutional logics and regional development in Australia." Entrepreneurship and Regional Development 27 (3-4): 219-254. doi:10.1080/08985626.2015.1030458.

Batjargal, Bat. 2003. "Social Capital and Entrepreneurial Performance in Russia: A Longitudinal Study." Organization Studies 24 (4): 535-556. doi:10.1177/0170840603024004002.

Battilana, Julie. 2006. "Agency and Institutions: The Enabling Role of Individuals' Social Position." Organization 13 (5): 653-676. doi:10.1177/1350508406067008.

Battilana, Julie, and Matthew Lee. 2014. "Advancing Research on Hybrid Organizing - Insights from the Study of Social Enterprises." Academy of Management Annals 8 (1): 397-441. doi:10.1080/19416520.2014.893615. 
Berglund, Henrik. 2007. "Researching Entrepreneurship as lived experience." In Handbook of qualitative research in entrepreneurship, edited by Helle Neergaard and John Parm Ulhøi, 75-93. Cheltenham: Edward Elgar. doi:10.4337/9781847204387.00011.

Berglund, Henrik. 2015. "Between cognition and discourse: phenomenology and the study of entrepreneurship." International Journal of Entrepreneurial Behavior \& Research 21 (3): 472-488. doi:10.1108/ijebr-122013-0210.

Bertacchini, Enrico E., and Paola Borrione. 2011. "The Geography of the Italian Creative Economy: The Special Role of the Design and Craft-based Industries." Regional Studies 47 (2): 135-147. doi:10.1080/00343404.2011.628652.

Bhagavatula, Suresh, Tom Elfring, Aad van Tilburg, and Gerhard G. van de Bunt. 2010. "How social and human capital influence opportunity recognition and resource mobilization in India's handloom industry." Journal of Business Venturing 25 (3): 245-260. doi:10.1016/j.jbusvent.2008.10.006.

Bourdieu, Pierre. 1977. Outline of a Theory of Practice. Cambridge, MA: Cambridge University Press.

Bourdieu, Pierre. 1984. Distinction: a social critique of the judgement of taste. Cambridge, MA: Harvard University Press.

Bourdieu, Pierre. 1986. The Forms of Capital. In The handbook of theory and research for the sociology of education, edited by J.G. Richardson, 241-258. New York, NY: Greenwood Press.

Bourdieu, Pierre. 1996. "On the Family as a Realized Category." Theory, Culture \& Society 13 (3): 19-26. doi:10.1177/026327696013003002.

Calás, Marta B., Linda Smircich, and Kristina A. Bourne. 2009. "Extending the Boundaries: Reframing "Entrepreneurship as Social Change" Through Feminist Perspectives." Academy of Management Review 34 (3): 552-569. doi:10.5465/amr.2009.40633597.

Chalmers, Dominic M., and Eva Balan-Vnuk. 2013. "Innovating not-for-profit social ventures: Exploring the microfoundations of internal and external absorptive capacity routines." International Small Business Journal 31 (7): 785-810. doi:10.1177/0266242612465630.

Chell, Elizabeth, Katerina Nicolopoulou, and Mine Karataş-Özkan. 2010. "Social entrepreneurship and enterprise: International and innovation perspectives." Entrepreneurship and Regional Development 22 
(6): 485-493. doi:10.1080/08985626.2010.488396.

Cope, Jason. 2005. "Researching Entrepreneurship through Phenomenological Inquiry: Philosophical and Methodological Issues." International Small Business Journal 23 (2): 163-189. doi:10.1177/0266242605050511.

Cope, Jason. 2011. "Entrepreneurial learning from failure: An interpretative phenomenological analysis." Journal of Business Venturing 26 (6): 604-623. doi:10.1016/j.jbusvent.2010.06.002.

Coulson, Susan. 2012. "Collaborating in a competitive world: musicians' working lives and understandings of entrepreneurship." Work, Employment \& Society 26 (2): 246-261. doi:10.1177/0950017011432919.

Dacin, Peter A., M. Tina Dacin, and Margaret Matear. 2010. "Social Entrepreneurship: Why We Don't Need a New Theory and How We Move Forward From Here." Academy of Management Perspectives 24 (3): 37-57. doi:10.5465/amp.2010.52842950.

Dana, Léo-Paul, and Ivan Light. 2011. "Two forms of community entrepreneurship in Finland: Are there differences between Finnish and Sámi reindeer husbandry entrepreneurs?" Entrepreneurship and Regional Development 23 (5-6): 331-352. doi:10.1080/08985626.2011.580163.

de Bruin, Anne, and Kate V. Lewis. 2015. "Traversing the Terrain of Context in Social Entrepreneurship." Journal of Social Entrepreneurship 6 (2): 127-136. doi:10.1080/19420676.2015.1038005.

De Clercq, Dirk, and Benson Honig. 2011. "Entrepreneurship as an integrating mechanism for disadvantaged persons." Entrepreneurship and Regional Development 23 (5-6): 353-372. doi:10.1080/08985626.2011.580164.

De Clercq, Dirk, and Maxim Voronov. 2009. "Toward a Practice Perspective of Entrepreneurship: Entrepreneurial Legitimacy as Habitus." International Small Business Journal 27 (4): 395-419. doi:10.1177/0266242609334971.

Defra (Department for Environment, Food and Rural Affairs). 2016. Defining rural areas. London: Defra. Di Domenico, MariaLaura, Helen Haugh, and Paul Tracey. 2010. "Social Bricolage: Theorizing Social Value Creation in Social Enterprises." Entrepreneurship Theory and Practice 34 (4): 681-703. doi:10.1111/j.1540-6520.2010.00370.x.

Di Domenico, MariaLaura, Paul Tracey, and Helen Haugh. 2009. "The Dialectic of Social Exchange: Theorizing 
Corporate-Social Enterprise Collaboration." Organization Studies 30 (8): 887-907. doi:10.1177/0170840609334954.

Downing, Stephen. 2005. "The Social Construction of Entrepreneurship: Narrative and Dramatic Processes in the Coproduction of Organizations and Identities." Entrepreneurship Theory and Practice 29 (2): 185-204. doi:10.1111/j.1540-6520.2005.00076.x.

Drakopoulou Dodd, Sarah, Seonaidh McDonald, Gerard McElwee, and Robert Smith. 2014. "A Bourdieuan Analysis of Qualitative Authorship in Entrepreneurship Scholarship." Journal of Small Business Management 52 (4): 633-654. doi:10.1111/jsbm.12125.

Drakopoulou Dodd, Sarah, Tobias Pret, and Eleanor Shaw. 2016. "Advancing Understanding of Entrepreneurial Embeddedness: Forms of Capital, Social Contexts and Time." In A Research Agenda for Entrepreneurship and Context, edited by William. B. Gartner and Friederike Welter, 120-133. Cheltenham: Edward Elgar. doi:10.4337/9781784716844.00014.

Drori, Israel, Benson Honig, and Mike Wright. 2009. "Transnational Entrepreneurship: An Emergent Field of Study." Entrepreneurship Theory and Practice 33 (5): 1001-1022. doi:10.1111/j.1540-6520.2009.00332.x. Edmondson, Amy C., and Stacy E. McManus. 2007. "Methodological Fit in Management Field Research." Academy of Management Review 32 (4): 1155-1179. doi:10.2307/20159361.

Eikhof, Doris Ruth, and Axel Haunschild. 2007. "For art's sake! Artistic and economic logics in creative production." Journal of Organizational Behavior 28 (5): 523-538. doi:10.1002/job.462.

Fillis, Ian. 2004. "The Internationalizing Smaller Craft Firm: Insights from the Marketing/Entrepreneurship Interface." International Small Business Journal 22 (1): 57-82. doi:10.1177/0266242604039481.

Fisher, Greg, Suresh Kotha, and Amrita Lahiri. 2016. "Changing with the Times: An Integrated View of Identity, Legitimacy and New Venture Life Cycles." Academy of Management Review 41 (3): 383-409. doi:10.5465/amr.2013.0496.

Gedajlovic, Eric, Benson Honig, Curt B. Moore, G. Tyge Payne, and Mike Wright. 2013. "Social Capital and Entrepreneurship: A Schema and Research Agenda." Entrepreneurship Theory and Practice 37 (3): $455-$ 478. doi:10.1111/etap.12042.

Glynn, Mary Ann, and Michael Lounsbury. 2005. "From the Critics' Corner: Logic Blending, Discursive Change 
and Authenticity in a Cultural Production System." Journal of Management Studies 42 (5): 1031-1055. doi:10.1111/j.1467-6486.2005.00531.x.

Granovetter, Mark. 1985. "Economic Action and Social Structure: The Problem of Embeddedness." American Journal of Sociology 91 (3): 481-510. doi:10.2307/2780199.

Haugh, Helen. 2007. "Community-Led Social Venture Creation." Entrepreneurship Theory and Practice 31 (2): 161-182. doi:10.1111/j.1540-6520.2007.00168.x.

Hindle, Kevin. 2010. "How community context affects entrepreneurial process: A diagnostic framework." Entrepreneurship and Regional Development 22 (7-8): 599-647. doi:10.1080/08985626.2010.522057.

Hite, Julie M. 2005. "Evolutionary Processes and Paths of Relationally Embedded Network Ties in Emerging Entrepreneurial Firms." Entrepreneurship Theory and Practice 29 (1): 113-144. doi:10.1111/j.15406520.2005.00072.x.

Jack, Sarah L., and Alistair R. Anderson. 2002. "The effects of embeddedness on the entrepreneurial process." Journal of Business Venturing 17 (5): 467-487. doi:10.1016/s0883-9026(01)00076-3.

Jennings, P. Devereaux, Royston Greenwood, Michael D. Lounsbury, and Roy Suddaby. 2013. "Institutions, entrepreneurs, and communities: A special issue on entrepreneurship." Journal of Business Venturing 28 (1): 1-9. doi:10.1016/j.jbusvent.2012.07.001.

Johannisson, Bengt, Marcela Ramírez-Pasillas, and Gösta Karlsson. 2002. "The institutional embeddedness of local inter-firm networks: a leverage for business creation." Entrepreneurship and Regional Development 14 (4): 297-315. doi:10.1080/08985620210142020.

Johnstone, Harvey, and Doug Lionais. 2004. "Depleted communities and community business entrepreneurship: revaluing space through place." Entrepreneurship and Regional Development 16 (3): 217-233. doi:10.1080/0898562042000197117.

Jones, Candace, Silviya Svejenova, Jesper Strandgaard Pedersen, and Barbara Townley. 2016. "Misfits, Mavericks and Mainstreams: Drivers of Innovation in the Creative Industries." Organization Studies 37 (6): 751-768. doi:10.1177/0170840616647671.

Jones, Trevor, Monder Ram, Paul Edwards, Alex Kiselinchev, and Lovemore Muchenje. 2014. "Mixed embeddedness and new migrant enterprise in the UK." Entrepreneurship and Regional Development 26 
(5-6): 500-520. doi:10.1080/08985626.2014.950697.

Karataş-Özkan, Mine. 2011. "Understanding relational qualities of entrepreneurial learning: Towards a multilayered approach." Entrepreneurship and Regional Development 23 (9-10): 877-906. doi:10.1080/08985626.2011.577817.

Kenworthy, Thomas, and W. Edward McMullan. 2013. "Finding Practical Knowledge in Entrepreneurship." Entrepreneurship Theory and Practice 37 (5): 983-997. doi:10.1111/etap.12048.

Khavul, Susanna, Helmuth Chavez, and Garry D. Bruton. 2013. "When institutional change outruns the change agent: The contested terrain of entrepreneurial microfinance for those in poverty." Journal of Business Venturing 28 (1): 30-50. doi:10.1016/j.jbusvent.2012.02.005.

Kistruck, Geoffrey M., and Paul W. Beamish. 2010. "The Interplay of Form, Structure, and Embeddedness in Social Intrapreneurship." Entrepreneurship Theory and Practice 34 (4): 735-761. doi:10.1111/j.15406520.2010.00371.x.

Knight, Frank Hyneman. 1921. Risk, uncertainty, and profit. Boston, MA: Houghton Mifflin.

Korsgaard, Steffen, and Alistair R. Anderson. 2011. "Enacting entrepreneurship as social value creation." International Small Business Journal 29 (2): 135-151. doi:10.1177/0266242610391936.

Korsgaard, Steffen, Richard Ferguson, and Johan Gaddefors. 2015. "The best of both worlds: how rural entrepreneurs use placial embeddedness and strategic networks to create opportunities." Entrepreneurship and Regional Development 27 (9-10): 574-598. doi:10.1080/08985626.2015.1085100.

Kuhn, Kristine M., and Tera L. Galloway. 2015. "With a Little Help From My Competitors: Peer Networking Among Artisan Entrepreneurs." Entrepreneurship Theory and Practice 39 (3): 571-600. doi: 10.1111/etap.12053.

Kvale, Steinar. 1989. "To validate is to question." In Issues of validity in qualitative research, edited by Steinar Kvale, 73-91. Lund, Sweden: Studentlitteratur.

Kwon, Seok-Woo, Colleen Heflin, and Martin Ruef. 2013. "Community Social Capital and Entrepreneurship." American Sociological Review 78 (6): 980-1008. doi:10.1177/0003122413506440.

Lang, Richard, Matthias Fink, and Ewald Kibler. 2014. "Understanding place-based entrepreneurship in rural Central Europe: A comparative institutional analysis." International Small Business Journal 32 (2): 204227. doi:10.1177/0266242613488614. 
Lather, Patti. 1993. "Fertile obsession: Validity after poststructuralism." Sociological Quarterly 34 (4): 673-693. doi:10.1111/j.1533-8525.1993.tb00112.x.

Le Breton-Miller, Isabelle, and Danny Miller. 2015. "The Arts and Family Business: Linking Family Business Resources and Performance to Industry Characteristics." Entrepreneurship Theory and Practice 39 (6): 1349-1370. doi:10.1111/etap.12177.

Lechner, Christian, and Christophe Leyronas. 2012. "The competitive advantage of cluster firms: the priority of regional network position over extra-regional networks - a study of a French high-tech cluster." Entrepreneurship and Regional Development 24 (5-6): 457-473. doi:10.1080/08985626.2011.617785.

Lee, Robert, Heinz Tüselmann, Dilani Jayawarna, and Julia Rouse. 2011. "Investigating the Social Capital and Resource Acquisition of Entrepreneurs Residing in Deprived Areas of England." Environment and Planning C: Government and Policy 29 (6): 1054-1072. doi:10.1068/c1188b.

Leitch, Claire M., Frances M. Hill, and Richard T. Harrison. 2010. "The Philosophy and Practice of Interpretivist Research in Entrepreneurship: Quality, Validation, and Trust." Organizational Research Methods 13 (1): 67-84. doi:10.1177/1094428109339839.

Lewis, Kate V. 2013. "The power of interaction rituals: The Student Volunteer Army and the Christchurch earthquakes." International Small Business Journal 31 (7): 811-831. doi:10.1177/0266242613478438.

Lewis, Kate V. 2015. "Enacting Entrepreneurship and Leadership: A Longitudinal Exploration of Gendered Identity Work." Journal of Small Business Management 53 (3): 662-682. doi:10.1111/jsbm.12175.

Lounsbury, Michael, and Mary Ann Glynn. 2001. "Cultural Entrepreneurship: Stories, Legitimacy, and the Acquisition of Resources." Strategic Management Journal 22 (6/7): 545-564. doi:10.2307/3094320.

Maclean, Mairi, Charles Harvey, and Jillian Gordon. 2013. "Social innovation, social entrepreneurship and the practice of contemporary entrepreneurial philanthropy." International Small Business Journal 31 (7): 747-763. doi:10.1177/0266242612443376.

Mair, Johanna, and Ignasi Martí. 2006. "Social entrepreneurship research: A source of explanation, prediction, and delight." Journal of World Business 41 (1): 36-44. doi:10.1016/j.jwb.2005.09.002.

Mair, Johanna, Ignasi Martí, and Marc J. Ventresca. 2012. "Building Inclusive Markets in Rural Bangladesh: How Intermediaries Work Institutional Voids." Academy of Management Journal 55 (4): 819-850. 
doi:10.5465/amj.2010.0627.

Markman, Gideon D., Michael Russo, G. T. Lumpkin, P. Devereaux Jennings, and Johanna Mair. 2016.

"Entrepreneurship as a Platform for Pursuing Multiple Goals: A Special Issue on Sustainability, Ethics, and Entrepreneurship." Journal of Management Studies 53 (5): 673-694. doi:10.1111/joms.12214.

Marquis, Christopher, Michael Lounsbury, and Royston Greenwood. 2011. "Introduction: Community as an Institutional Order and a Type of Organizing." In Communities and Organizations, edited by Christopher Marquis, Michael Lounsbury and Royston Greenwood, ix-xxvii. Bingley: Emerald Group Publishing Limited. doi:10.1108/S0733-558X(2011)0000033003.

Martí, Ignasi, David Courpasson, and Saulo Dubard Barbosa. 2013. "'Living in the fishbowl'. Generating an entrepreneurial culture in a local community in Argentina." Journal of Business Venturing 28 (1): 10-29. doi:10.1016/j.jbusvent.2011.09.001.

Marvel, Matthew R., Justin L. Davis, and Curtis R. Sproul. 2016. "Human Capital and Entrepreneurship Research: A Critical Review and Future Directions." Entrepreneurship Theory and Practice 40 (3): 599-626. doi:10.1111/etap.12136.

Maurer, Indre, and Mark Ebers. 2006. "Dynamics of Social Capital and Their Performance Implications: Lessons from Biotechnology Start-ups." Administrative Science Quarterly 51 (2): 262-292. doi:10.2189/asqu.51.2.262.

McKeever, Edward, Alistair R. Anderson, and Sarah L. Jack. 2014. "Entrepreneurship and mutuality: social capital in processes and practices." Entrepreneurship and Regional Development 26 (5-6): 453-477. doi:10.1080/08985626.2014.939536.

McKeever, Edward, Sarah L. Jack, and Alistair R. Anderson. 2015. "Embedded entrepreneurship in the creative re-construction of place." Journal of Business Venturing 30 (1): 50-65. doi:10.1016/j.jbusvent.2014.07.002.

McLeod, Charlotte, Stephanie O'Donohoe, and Barbara Townley. 2011. "Pot Noodles, Placements and Peer Regard: Creative Career Trajectories and Communities of Practice in the British Advertising Industry." British Journal of Management 22 (1): 114-131. doi:10.1111/j.1467-8551.2010.00705.x.

McMullen, Jeffery S., and Dimo Dimov. 2013. "Time and the Entrepreneurial Journey: The Problems and Promise of Studying Entrepreneurship as a Process." Journal of Management Studies 50 (8): 14811512. doi:10.1111/joms. 12049 
McMullen, Jeffery S., and Benjamin J. Warnick. 2016. "Should We Require Every New Venture to Be a Hybrid Organization?" Journal of Management Studies 53 (4): 630-662. doi:10.1111/joms.12150.

Miller, Toyah, Matthew Grimes, Jeffery McMullen, and Timonthy Vogus. 2012. "Venturing for Others with Heart and Head: How Compassion Encourages Social Entrepreneurship." Academy of Management Review 37 (4): 616-640. doi:10.5465/amr.10.0456.

Nicholls, Alex. 2010. "The Legitimacy of Social Entrepreneurship: Reflexive Isomorphism in a Pre-Paradigmatic Field." Entrepreneurship Theory and Practice 34 (4): 611-633. doi:10.1111/j.1540-6520.2010.00397.x.

Nicolopoulou, Katerina. 2014. "Social Entrepreneurship between Cross-Currents: Toward a Framework for Theoretical Restructuring of the Field." Journal of Small Business Management 52 (4): 678-702. doi:10.1111/jsbm.12130.

O'Mahony, Siobhán, and Fabrizio Ferraro. 2007. "The Emergence of Governance in an Open Source Community." Academy of Management Journal 50 (5): 1079-1106. doi:10.5465/amj.2007.27169153.

Özbilgin, Mustafa, and Ahu Tatli. 2005. "Book Review Essay: Understanding Bourdieu's Contribution to Organization and Management Studies." Academy of Management Review 30 (4): 855-869. doi:10.5465/amr.2005.18378882.

Ozcan, Pinar, and Kathleen M. Eisenhardt. 2009. "Origin of alliance portfolios: entrepreneurs, network strategies, and firm performance." Academy of Management Journal 52 (2): 246-279. doi:10.5465/amj.2009.37308021.

Pache, Anne-Claire, and Filipe Santos. 2013. "Inside the Hybrid Organization: Selective Coupling as a Response to Competing Institutional Logics." Academy of Management Journal 56 (4): 972-1001. doi:10.5465/amj.2011.0405.

Parkinson, Caroline, and Carole Howorth. 2008. "The language of social entrepreneurs." Entrepreneurship and Regional Development 20 (3): 285-309. doi:10.1080/08985620701800507.

Parkinson, Caroline, Carole Howorth, and Alan Southern. Forthcoming. "The crafting of an (un)enterprising community: Context and the social practice of talk." International Small Business Journal. doi:10.1177/0266242615621123.

Patton, Michael Quinn. 2015. Qualitative research and evaluation methods. 4th ed. Thousand Oaks, CA: Sage Pearce, John A., and Jonathan P. Doh. 2005. "The high impact of collaborative social initiatives." MIT Sloan 
Management Review 46 (3): 29-39.

Peredo, Ana María, and Murdith McLean. 2006. "Social entrepreneurship: A critical review of the concept." Journal of World Business 41 (1): 56-65. doi:10.1016/j.jwb.2005.10.007.

Phelps, Corey, Ralph Heidl, and Anu Wadhwa. 2012. "Knowledge, Networks, and Knowledge Networks: A Review and Research Agenda." Journal of Management 38 (4): 1115-1166. doi:10.1177/0149206311432640. Pret, Tobias, Eleanor Shaw, and Sarah Drakopoulou Dodd. 2016. "Painting the Full Picture: The Conversion of Economic, Cultural, Social and Symbolic Capital." International Small Business Journal 34 (8): 10041027. doi:10.1177/0266242615595450.

Rooks, Gerrit, Kim Klyver, and Arthur Sserwanga. 2016. "The Context of Social Capital: A Comparison of Rural and Urban Entrepreneurs in Uganda." Entrepreneurship Theory and Practice 40 (1): 111-130. doi:10.1111/etap.12107.

Sandberg, Jörgen. 2000. "Understanding Human Competence at Work: An Interpretative Approach." Academy of Management Journal 43 (1): 9-25. doi:10.2307/1556383.

Sandberg, Jörgen. 2005. "How Do We Justify Knowledge Produced Within Interpretive Approaches?" Organizational Research Methods 8 (1): 41-68. doi:10.1177/1094428104272000.

Schumpeter, Joseph Alois. 1942. Capitalism, socialism and democracy. New York, NY: Harper \& Row.

Schwarz, Mary, and Karen Yair. (2010). Making Value: craft and the economic and social contribution of makers. London: Crafts Council.

Scott, Allen J. 2006. "Entrepreneurship, Innovation and Industrial Development: Geography and the Creative Field Revisited." Small Business Economics 26 (1): 1-24. doi:10.1007/s11187-004-6493-9.

Shaw, Eleanor, and Anne de Bruin. 2013. "Reconsidering capitalism: the promise of social innovation and social entrepreneurship?" International Small Business Journal 31 (7): 737-746. doi:10.1177/0266242613497494.

Shaw, Eleanor, and Sara Carter. 2007. "Social entrepreneurship: Theoretical antecedents and empirical analysis of entrepreneurial processes and outcomes." Journal of Small Business and Enterprise Development 14 (3): 418-434. doi:10.1108/14626000710773529.

Shaw, Eleanor, Juliette Wilson, and Tobias Pret. Forthcoming. "The process of embedding a small firm in its industrial context." International Small Business Journal. doi:10.1177/0266242616671170. 
Shepherd, Dean A. 2015. "Party On! A call for entrepreneurship research that is more interactive, activity based, cognitively hot, compassionate, and prosocial." Journal of Business Venturing 30 (4): 489-507. doi:10.1016/j.jbusvent.2015.02.001.

Short, Jeremy C., Todd W. Moss, and G. T. Lumpkin. 2009. "Research in social entrepreneurship: past contributions and future opportunities." Strategic Entrepreneurship Journal 3 (2): 161-194. doi:10.1002/sej.69.

Smith, Brett R., and Christopher E. Stevens. 2010. "Different types of social entrepreneurship: The role of geography and embeddedness on the measurement and scaling of social value." Entrepreneurship and Regional Development 22 (6): 575-598. doi:10.1080/08985626.2010.488405.

Smith, Jonathan A. 2004. "Reflecting on the development of interpretative phenomenological analysis and its contribution to qualitative research in psychology." Qualitative Research in Psychology 1 (1): 39-54. doi:10.1191/1478088704qp004oa.

Smith, Jonathan A., Paul Flowers, and Michael Larkin. 2009. Interpretative Phenomenological Analysis: Theory Method and Research. London: Sage.

Sorenson, Ritch L., Cathleen A. Folker, and Keith H. Brigham. 2008. "The Collaborative Network Orientation: Achieving Business Success through Collaborative Relationships." Entrepreneurship Theory and Practice 32 (4): 615-634. doi:10.1111/j.1540-6520.2008.00245.x.

Spigel, Ben. 2013. "Bourdieuian approaches to the geography of entrepreneurial cultures." Entrepreneurship and Regional Development 25 (9-10): 804-818. doi:10.1080/08985626.2013.862974.

Stevens, Robin, Nathalie Moray, and Johan Bruneel. 2015. "The Social and Economic Mission of Social Enterprises: Dimensions, Measurement, Validation, and Relation." Entrepreneurship Theory and Practice 39 (5): 1051-1082. doi:10.1111/etap.12091.

Stringfellow, Lindsay, Eleanor Shaw, and Mairi Maclean. 2014. "Apostasy versus legitimacy: Relational dynamics and routes to resource acquisition in entrepreneurial ventures." International Small Business Journal 32 (5): 571-592. doi:10.1177/0266242612471693.

Tan, Justin, Yunfei Shao, and Wan Li. 2013. "To be different, or to be the same? An exploratory study of isomorphism in the cluster." Journal of Business Venturing 28 (1): 83-97. 
doi:10.1016/j.jbusvent.2012.02.003.

Tapsell, Paul, and Christine Woods. 2010. "Social entrepreneurship and innovation: Self-organization in an indigenous context." Entrepreneurship and Regional Development 22 (6): 535-556. doi:10.1080/08985626.2010.488403.

Terjesen, Siri, and Amanda Brickman Elam. 2009. "Transnational Entrepreneurs' Venture Internationalization Strategies: A Practice Theory Approach." Entrepreneurship Theory and Practice 33 (5): 1093-1120. doi:10.1111/j.1540-6520.2009.00336.x.

Tregear, Angela. 2005. "Lifestyle, growth, or community involvement? The balance of goals of UK artisan food producers." Entrepreneurship and Regional Development 17 (1): 1-15. doi:10.1080/08985620420002497777.

Uzzi, Brian. 1997. "Social Structure and Competition in Interfirm Networks: The Paradox of Embeddedness." Administrative Science Quarterly 42 (1): 35-67. doi:10.2307/2393808.

Vershinina, Natalia, Rowena Barrett, and Michael Meyer. 2011. "Forms of capital, intra-ethnic variation and Polish entrepreneurs in Leicester." Work, Employment \& Society 25 (1): 101-117. doi:10.1177/0950017010389241.

Welter, Friederike. 2011. "Contextualizing Entrepreneurship-Conceptual Challenges and Ways Forward." Entrepreneurship Theory and Practice 35 (1): 165-184. doi:10.1111/j.1540-6520.2010.00427.x.

Wry, Tyler, and Jeffrey York. Forthcoming. "An Identity Based Approach to Social Enterprise." Academy of Management Review. doi:10.5465/amr.2013.0506.

Zahra, Shaker A., Eric Gedajlovic, Donald O. Neubaum, and Joel M. Shulman. 2009. "A typology of social entrepreneurs: Motives, search processes and ethical challenges." Journal of Business Venturing 24 (5): 519-532. doi:10.1016/j.jbusvent.2008.04.007.

Zahra, Shaker A., and Mike Wright. 2016. "Understanding the Social Role of Entrepreneurship." Journal of Management Studies 53 (4): 610-629. doi:10.1111/joms.12149.

Zahra, Shaker A., Mike Wright, and Sondos G. Abdelgawad. 2014. "Contextualization and the advancement of entrepreneurship research." International Small Business Journal 32 (5): 479-500. doi:10.1177/0266242613519807. 
Figure 1. Bourdieu's theory of practice

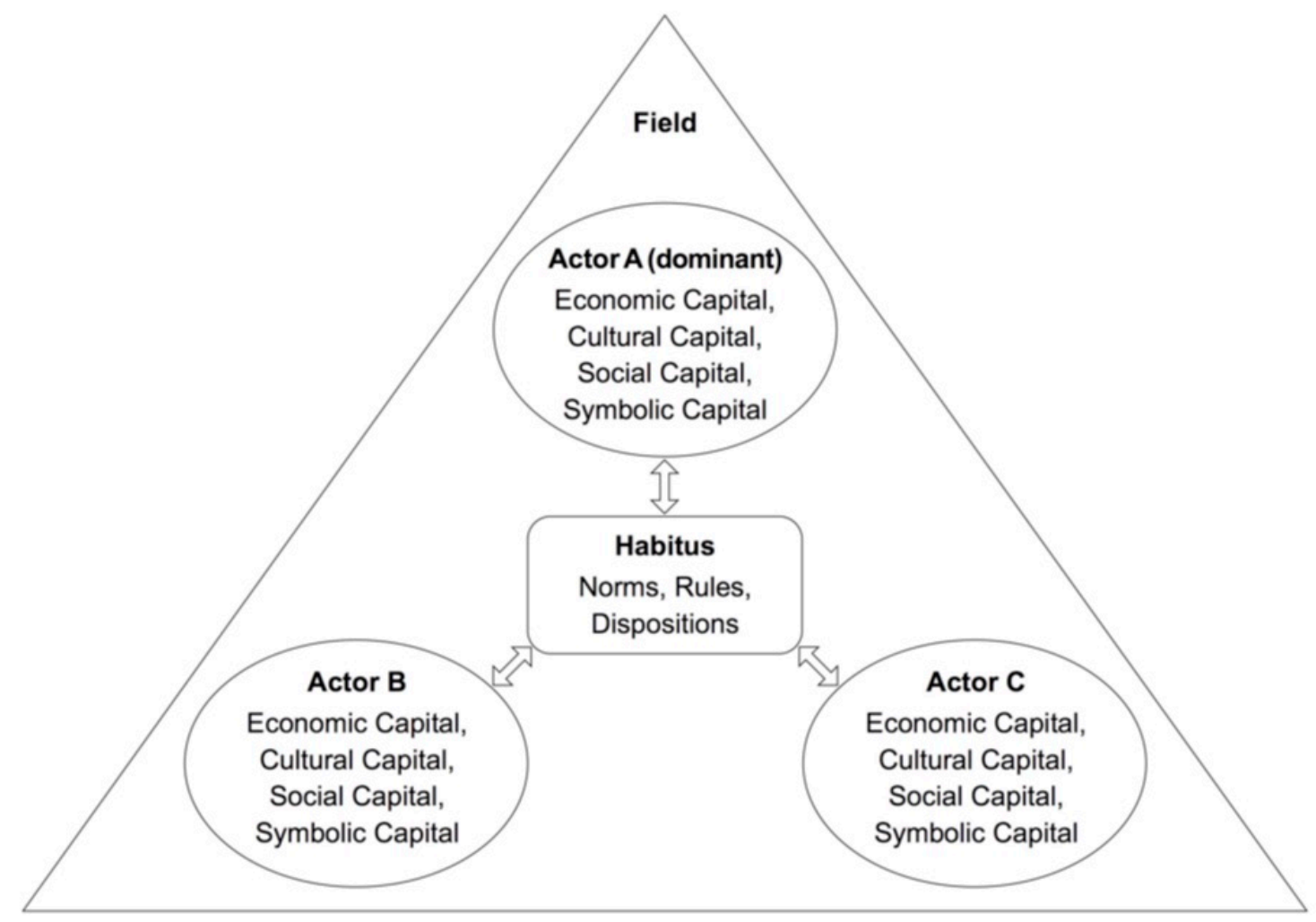

Table 1. Data analysis process

\begin{tabular}{ll}
\hline Step & Description \\
\hline 1. Familiarising & $\begin{array}{l}\text { After each round of interviews, we read and re-read transcripts, observation notes and other } \\
\text { documents to familiarise ourselves with the data (Pret, Shaw, and Drakopoulou Dodd 2016). }\end{array}$ \\
2. Categorising & $\begin{array}{l}\text { We then highlighted potentially significant passages in the transcripts, which enabled the } \\
\text { discovery and coding of emerging themes that appeared salient to each individual interview } \\
\text { (Lewis 2015). }\end{array}$ \\
3. Associating & $\begin{array}{l}\text { Next, we compared themes between participants' interviews and searched for patterns to } \\
\text { develop superordinate categories (Smith, Flowers, and Larkin 2009). This process allowed } \\
\text { us to develop topic guides that we used to direct subsequent rounds of interviews. }\end{array}$ \\
4. Interpreting & $\begin{array}{l}\text { Afterwards, we prepared interpretive summaries, which we shared with participants to gain } \\
\text { their feedback on our interpretations (Cope 2011). }\end{array}$ \\
5. Explaining & $\begin{array}{l}\text { Finally, we compared our findings to concepts in the literature. This abstraction process } \\
\text { involved moving iteratively between existing theory and our data to gain a higher level of } \\
\text { conceptualisation (Edmondson and McManus 2007). }\end{array}$ \\
\hline
\end{tabular}


Table 2. Conventions within craft communities

\begin{tabular}{ll}
\hline Convention & Representative quotation \\
\hline Positivity & 'They don't like to hear [the] negative ... I get the impression that nobody ever has any \\
& problems and once you had a problem ... you're almost like tarnished'. (Debra) \\
& 'You just have to be nice and ... sometimes that can be quite exhausting'. (Cheryl) \\
Camaraderie & 'I do feel a connection with people who make things ... it's quite sort of close, you know, their \\
& needs and their concerns ... are the same ... [so] I help out'. (Ethan) \\
& 'I value their [peers] friendship and ... I know what it's taken to get mine [business] off the \\
& ground, so I, you know, I try and help'. (Georgia) \\
Moral Support & 'When you've made things that you sell, you know how much work goes into [it].... I always \\
& feel like, empathy for people [peers] at craft fairs ... [so] I always talk to them and take their \\
& cards and show an interest'. (Faith) \\
& 'People that have got good ideas ... if they've got ... the courage and get up and do something \\
& with it ... I think all credit to them, because it's not easy! ... Whenever I come across ... \\
& [peers] I will always make a point of congratulating them'. (Irene) \\
& 'I think people who make crafts, I mean obviously there are always nice and nasty people, but \\
& generally it's like a little community ... everybody knows nobody is making a lot of money, \\
but ... people do try and help, people help out a lot'. (Jacob)
\end{tabular}

Table 3. Strategic changes of behaviours

\begin{tabular}{ll}
\hline Strategic action & Representative quotation \\
\hline Pretending & 'If you are running an online business the persona that you are presenting online, even if it \\
& does get a little bit personal, is still your kind of business persona. You ... paint this picture of \\
& your life ... so they think that you are this very interesting person'. (Beth) \\
Restraining & 'I don't swear as much ... I'm trying to be more professional and stuff. I'm still quite chatty, \\
& ... but I think that sort of ... make[s] people feel at ease'. (Faith) \\
& 'Obviously with clients I have to be totally professional ... I can be more upfront with family, \\
& 'cos you know, you can say what you mean'. (Helen) \\
Concealing & 'Generally I put a positive spin on everything that is happening ... especially if I'm talking to \\
& people that I don't know particularly well'. (Cheryl) \\
& 'You don't want people to know that, when nobody sees you, you sit about wearing slippers \\
& shaped like dogs ... [so] you take the picture of the bit of the house that looks nice .... so you \\
& do have to edit to a certain extent'. (Beth) \\
'At shows and things like that I'm always delightful and happy and a little ray of sunshine and \\
Performing & at home I'm horrible [laughs]'. (Alice) \\
& 'I'm aware, when I'm talking to somebody who's always lived here, that I probably sound \\
& quite posh, so ... I change ... how I speak to people'. (Jacob)
\end{tabular}


Table 4. Motivations for collaboration and capital sharing

\begin{tabular}{|c|c|}
\hline Motivation & Representative quotation \\
\hline \multirow[t]{2}{*}{ Conservation } & $\begin{array}{l}\text { 'If we don't kind of help each other out ... there is not gonna be any makers left. It's all } \\
\text { gonna be stuff that you buy at Primark for two quid [pound sterling]'. (Beth) }\end{array}$ \\
\hline & $\begin{array}{l}\text { 'People doing things well and passing on those skills ... that is really important for our } \\
\text { generations to come, that there are still people who do that'. (Georgia) }\end{array}$ \\
\hline \multirow[t]{2}{*}{ Solidarity } & $\begin{array}{l}\text { 'I think it's because we're all in the same boat, we are all individual makers, that you want to } \\
\text { kind of help one another out'. (Cheryl) }\end{array}$ \\
\hline & $\begin{array}{l}\text { 'You tend to find ... you want to help one another out, because you would hope .... that } \\
\text { somebody else would do the same for you'. (Debra) }\end{array}$ \\
\hline \multirow[t]{2}{*}{ Altruism } & $\begin{array}{l}\text { 'I give free time, free design-work, to help [others] ... It's not driven to pay the mortgage ... } \\
\text { it's nice ... I've got a real buzz going on inside'. (Irene) }\end{array}$ \\
\hline & 'I think it's important to help people and to give back in some way'. (Faith) \\
\hline Empathy & $\begin{array}{l}\text { 'I've ... spoken to the fashion class, ... 'cos I know how hard it is when you're a student. ... I } \\
\text { would have loved somebody to have told me how they set up on their own, so I think the } \\
\text { knowledge ... I can offer will be invaluable'. (Helen) }\end{array}$ \\
\hline
\end{tabular}

Table 5. Reasons for indifference concerning plagiarism

\begin{tabular}{|c|c|}
\hline Reason & Representative quotation \\
\hline Individuality & $\begin{array}{l}\text { 'I'm not worried at all, 'cos hopefully there will be other customers out there. ... There is } \\
\text { obviously the chance that they [students] will then start making and selling, but they are still } \\
\text { not me and ... they will never do what I do'. (Alice) }\end{array}$ \\
\hline \multirow[t]{2}{*}{ Experience } & $\begin{array}{l}\text { 'Somebody else might see that and think, "Oh, right, I'll copy that", but they wouldn't be able } \\
\text { to copy it with the same ... sort of precision and skill'. (Ethan) }\end{array}$ \\
\hline & $\begin{array}{l}\text { 'I've noticed on Pinterest ... people have pinned my wallets and ... put things like 'I'll try } \\
\text { later", but nobody has done it. ... I don't know that anyone would be able to do quite as good a } \\
\text { job, 'cos it has taken me years to develop it'. (Helen) }\end{array}$ \\
\hline Integrity & $\begin{array}{l}\text { 'The integrity of the design has to be right and you can't ... copy other people, ... it's my } \\
\text { design reputation on the line if I copy something else'. (Cheryl) }\end{array}$ \\
\hline \multirow[t]{2}{*}{ Exclusion } & $\begin{array}{l}\text { 'I've been doing it [style] for years and there was somebody who had stuff [copies] up on } \\
\text { Etsy ... I had customers messaging me saying, "Do you know this person is doing this?" ... } \\
\text { So, I don't think you can [plagiarise], really ... because it is such a small community and .... } \\
\text { people like to gossip about the negative things'. (Beth) }\end{array}$ \\
\hline & $\begin{array}{l}\text { 'If you work over time, you get to know people. ... If you behave unethically I can tell you it } \\
\text { will come around and bite you in ... years to come'. (Irene) }\end{array}$ \\
\hline
\end{tabular}


Appendix 1. Participant Profiles

\begin{tabular}{|c|c|}
\hline Participant & Background, experience and career \\
\hline $\begin{array}{l}\text { Alice } \\
\text { (early-30s) }\end{array}$ & $\begin{array}{l}\text { As a teddy bear maker, Alice engages in a contemporary craft. Originally trained in costume } \\
\text { design, she decided to change profession when her sister's teddy bear business became } \\
\text { successful. Alice has practised this trade independently for over } 15 \text { years and has won some of } \\
\text { the most prestigious awards in the industry. }\end{array}$ \\
\hline $\begin{array}{l}\text { Beth } \\
\text { (mid-30s) }\end{array}$ & $\begin{array}{l}\text { Born and raised in North America, Beth became aware of the internationally growing demand } \\
\text { for hand-dyed yarn earlier than most craftspeople in the UK. She seized the opportunity and } \\
\text { opened her studio in } 2007 \text {. Beforehand, Beth studied English literature and run her own } \\
\text { instrument repair enterprise for two years. }\end{array}$ \\
\hline $\begin{array}{l}\text { Cheryl } \\
\text { (mid-40s) }\end{array}$ & $\begin{array}{l}\text { After earning a degree in printed textiles and working as an independent textile designer for } \\
\text { over } 15 \text { years, Cheryl decided to seek a new challenge and start her own hand-stitching } \\
\text { business. She opened her studio in } 2007 \text { but, three months into our study, decided to work } \\
\text { from home again to gain more time for her design work. }\end{array}$ \\
\hline $\begin{array}{l}\text { Debra } \\
\text { (late-30s) }\end{array}$ & $\begin{array}{l}\text { When Debra started studying silversmithing in } 1995 \text {, the profession was dominated by men. } \\
\text { She managed to succeed in this competitive craft by gaining international acclaim for her } \\
\text { work. Since moving into her studio in } 2004 \text {, Debra has won several awards and a number of her } \\
\text { pieces were selected for display in national museums. }\end{array}$ \\
\hline $\begin{array}{l}\text { Ethan } \\
\text { (early-50s) }\end{array}$ & $\begin{array}{l}\text { Raised in the Baltics, Ethan was trained in the European approach to basket weaving before he } \\
\text { learned the British technique. Developing these rare skills helped him find work with several } \\
\text { employers, which prepared him for opening his studio in } 2004 \text {. }\end{array}$ \\
\hline $\begin{array}{l}\text { Faith } \\
\text { (early-50s) }\end{array}$ & $\begin{array}{l}\text { After studying geography at university, Faith worked for a library, where she was engaged in } \\
\text { introducing children to reading. She now capitalises on her creativity by designing children's } \\
\text { playbooks, for which she perceives a growing demand. }\end{array}$ \\
\hline $\begin{array}{l}\text { Georgia } \\
\text { (mid-60s) }\end{array}$ & $\begin{array}{l}\text { Georgia studied English, Fine Art and Education and worked as a lecturer in the arts } \\
\text { department at university. She therefore possessed a wealth of relevant experience, which } \\
\text { prepared her for opening a print making business in } 2006 \text {. Presenting her work in solo- } \\
\text { exhibitions raised Georgia's profile internationally. }\end{array}$ \\
\hline $\begin{array}{l}\text { Helen } \\
\text { (late-20s) }\end{array}$ & $\begin{array}{l}\text { Following a degree in fashion, Helen set up a wallet making business with two friends, who } \\
\text { taught her valuable business skills. As she wanted to grow the venture faster than her friends } \\
\text { permitted, Helen left to start her own firm in } 2011 \text {, crafting accessories. She now considers } \\
\text { selling off this venture and creating a fashion label. }\end{array}$ \\
\hline $\begin{array}{l}\text { Irene } \\
\text { (early-60s) }\end{array}$ & $\begin{array}{l}\text { After being trained in ceramics at university, Irene worked for the same employer for most of } \\
\text { her life. In } 2010 \text { Irene discovered a lack of individualised souvenirs for her local area, so she } \\
\text { decided to set up a business and create such products to maximise her savings for retirement. }\end{array}$ \\
\hline $\begin{array}{l}\text { Jacob } \\
\text { (mid-40s) }\end{array}$ & $\begin{array}{l}\text { While studying medicine, Jacob discovered his passion for ceramics. He decided to pursue this } \\
\text { interest by training in pottery at college. Jacob started his business and moved into his } \\
\text { workshop only weeks before our study commenced. }\end{array}$ \\
\hline
\end{tabular}

